\title{
Dual- and Triple-Acting Agents for Treating Core and Co-morbid Symptoms of Major Depression: Novel Concepts, New Drugs
}

\author{
Mark J. Millan \\ Psychopharmacology Department, Institut du Recherches Servier, Centre de Recherches de Croissy, Paris, France
}

\begin{abstract}
Summary: The past decade of efforts to find improved treatment for major depression has been dominated by genomedriven programs of rational drug discovery directed toward highly selective ligands for nonmonoaminergic agents. Selective drugs may prove beneficial for specific symptoms, for certain patient subpopulations, or both. However, network analyses of the brain and its dysfunction suggest that agents with multiple and complementary modes of action are more likely to show broad-based efficacy against core and comorbid symptoms of depression. Strategies for improved multitarget exploitation of monoaminergic mechanisms include triple inhibitors of dopamine, serotonin (5-HT) and noradrenaline reuptake, and drugs interfering with feedback actions of monoamines at inhibitory $5-\mathrm{HT}_{1 \mathrm{~A}}, 5-\mathrm{HT}_{1 \mathrm{~B}}$ and possibly $5-\mathrm{HT}_{5 \mathrm{~A}}$ and $5-\mathrm{HT}_{7}$ receptors. Specific subsets of postsynaptic 5-HT receptors mediating antidepressant actions are under study (e.g., 5-HT $\mathrm{H}_{4}$ and $5-\mathrm{HT}_{6}$ ). Association of a clinically characterized antidepressant
\end{abstract}

mechanism with a nonmonoaminergic component of activity is an attractive strategy. For example, agomelatine (a melatonin agonist/5- $\mathrm{HT}_{2 \mathrm{C}}$ antagonist) has clinically proven activity in

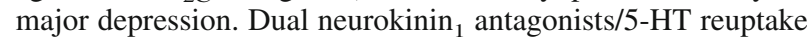

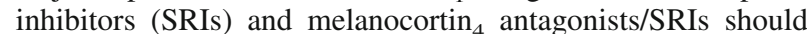
display advantages over their selective counterparts, and histamine $\mathrm{H}_{3}$ antagonists/SRIs, GABA $\mathrm{B}_{\mathrm{B}}$ antagonists/SRIs, glutamatergic/SRIs, and cholinergic agents/SRIs may counter the compromised cognitive function of depression. Finally, drugs that suppress 5-HT reuptake and blunt hypothalamo-pituitary-adrenocorticotrophic axis overdrive, or that act at intracellular proteins such as GSK-3 $\beta$, may abrogate the negative effects of chronic stress on mood and neuronal integrity. This review discusses the discovery and development of dual- and tripleacting antidepressants, focusing on novel concepts and new drugs disclosed over the last 2 to 3 years. Key Words: Antidepressant, multitarget, network, stress, HPA axis, CRF.

\section{FROM HIGHLY SELECTIVE AGENTS TO MULTITARGET ANTIDEPRESSANTS}

Major depression is a common, heterogeneous, and often incapacitating disorder triggered by a complex pattern of genetic, epigenetic, developmental, and environmental factors. ${ }^{1}$ Although commonly used antidepressants, such as the selective serotonin (5-HT) reuptake inhibitor (SSRI) fluoxetine, are often effective, full efficacy is only apparent after several weeks; and many patients only partially respond, and some remain refractory. Accordingly, considerable efforts are invested in the search for better drugs (and other, nonpharmacotherapeutic approaches) for more effective treatment of

Address correspondence and reprint requests to: Mark J. Millan, IDR Servier, Psychopharmacology Dept., 125 chemin de Ronde, 78290 Croissy-sur-Seine, Paris, France. E-mail: mark.millan@fr.netgrs.com. depression. ${ }^{2-8}$ There is a need for improved control not just of affective deficits, but also of other symptoms, such as insomnia, circadian desynchronization, sexual dysfunction, cognitive impairment, and pain. Moreover, depression shows high comorbidity with other serious CNS disorders (Table 1). ${ }^{3,7}$

All currently available antidepressants harness monoaminergic mechanisms. The past decade has witnessed a genome-driven focus on the rational discovery of highly selective drugs acting at innovative, nonmonoaminergic targets (FIG. 1) ${ }^{3-9}$ Along with genetically modified mice as animal models, such agents are vital in the experimental and therapeutic exploration of novel drug targets and hypotheses. In addition, selective antidepressants may prove helpful against particular symptoms and in discrete subpopulations of patients who have specific pathologies. ${ }^{1,3}$ Nonetheless, agents that interact with several complementary targets or with distributed cerebral networks (or with both) offer greater hope for the broad- 
Table 1. Symptoms and CNS Disorders Frequently Comorbid with Major Depression

\begin{tabular}{|c|c|c|c|c|c|c|c|c|c|}
\hline \multirow[b]{2}{*}{ Disorder } & \multicolumn{9}{|c|}{ Symptom } \\
\hline & $\begin{array}{l}\text { Depressed } \\
\text { Mood }\end{array}$ & Anxiety & $\begin{array}{c}\text { Cognitive } \\
\text { Perturbation* }\end{array}$ & $\begin{array}{c}\text { Decreased } \\
\text { Sleep } \\
\text { Quality }\end{array}$ & $\begin{array}{l}\text { Circadian } \\
\text { Disruption }\end{array}$ & $\begin{array}{c}\text { Sexual } \\
\text { Dysfunction }\end{array}$ & $\begin{array}{l}\text { Psychosis } \\
\text { or Mania }\end{array}$ & Pain & $\begin{array}{c}\text { Motor } \\
\text { Retardation } \\
\text { or } \\
\text { Excitation }\end{array}$ \\
\hline Major depression & +++ & ++ & ++ & ++ & ++ & + & + & + & ++ \\
\hline Anxiety disorders & ++ & +++ & ++ & ++ & + & + & - & + & ++ \\
\hline Bipolar disorder & ++ & + & ++ & ++ & ++ & + & $+++^{\dagger}$ & - & + \\
\hline OCD & + & $++^{\ddagger}$ & ++ & + & + & + & + & - & + \\
\hline Schizophrenia & + & + & ++ & + & + & + & +++ & + & ++ \\
\hline Parkinson's & ++ & + & ++ & ++ & + & ++ & + & ++ & +++ \\
\hline Alzheimer's & + & + & +++ & ++ & ++ & NR & ++ & - & ++ \\
\hline Epilepsy & + & + & ++ & ++ & + & + & - & + & - \\
\hline Stroke & ++ & + & +++ & + & + & + & + & ++ & ++ \\
\hline Chronic pain & ++ & ++ & + & ++ & + & ++ & + & +++ & ++ \\
\hline
\end{tabular}

$\mathrm{OCD}=$ obsessive compulsive disorder; $\mathrm{NR}=$ not usually relevant; $+++=$ cardinal; $++=$ prominent; $+=$ well recognized; $-=$ not characteristic.

*Cognitive perturbation is a complex construct, with patterns of disruption differing markedly among disorders.

${ }^{\dagger}$ Mania.

Cause? Or consequence? Or both?

based and efficacious treatment of both cardinal and comorbid symptoms of depression. ${ }^{3,7,10-16}$

The present author has, elsewhere, comprehensively discussed conceptual bases underpinning multitarget antidepressants, and reviewed a broad range of mechanisms implicated in the pathogenesis and potentially improved control of affective disorders. ${ }^{3}$ The present review outlines the principal advances of the last few years, focusing on the discovery and development of drugs that have dual and triple mechanisms of antidepressant activity.

\section{THE SEARCH FOR DUAL- AND TRIPLE- ACTING ANTIDEPRESSANTS: RATIONALE}

Numerous arguments support the contention that multitarget mechanisms may be more effective and better tolerated than their highly selective counterparts in the management of CNS disorders (see elsewhere in this issue). Several lines of evidence specifically substantiate interest in dual- and triple-acting antidepressants.

First, there is no single cause of major depression. Rather, a vast array of interacting genes, epigenetic influences, developmental events, and environmental influences collectively (and often synergistically) compromise mood and trigger affective disorders. ${ }^{1}$ Despite contemporary notions of endophenotype (i.e., gene-related dysfunction specific to an individual), genetic screening, and individual medicine, ${ }^{1,17}$ treatment strategies with a broad influence on corticolimbic circuits implicated in depression are more likely than highly selective agents to be effective in significant patient numbers.
Second, agents that have complementary components of action have a greater chance of controlling both the mood deficits of depression and other symptoms reflecting contrasting pathophysiological substrates, such as mnemonic deficits, desynchronization, and pain. ${ }^{1,3}$

Third, coadministration of various classes of adjunctive agent, from lithium to atypical antipsychotics to thyroxine, reinforces the efficacy of SSRIs. ${ }^{3,18-22}$ This is clearly not equivalent to an increase in dose: improved efficacy reflects engagement of mechanisms complementary to 5-HT reuptake inhibition-not just more of the same, but something different on top.

Fourth, prototypical drugs for the treatment of other major psychiatric and neurological disorders act via a diversity of neuronal mechanisms distributed across many cerebral regions (Table 2). Similarly, pharmacological, somatic, and psychological approaches for relieving depression are unlikely to act via any common unitary mechanism.

Fifth, in line with this assertion, sleep deprivation (rapidly effective) and electroconvulsive therapy (active in many drug-refractory patients), as well as deep brain stimulation, transcranial magnetic stimulation, and vagal nerve stimulation (although data are less extensive), engage a broad array of molecular substrates s,6,7,23 $^{3, \text { and, as }}$ suggested by imaging studies, extensive cerebral circuits (Table 3). ${ }^{23-27}$ The same holds for psychological approaches such as cognitive-behavioral therapy, which likewise affect overarching cerebral networks rather than any single circumscribed brain region. ${ }^{28-30}$ This is a far cry, then, from a highly selective drug targeting a single protein (Table 3). Ideally, one should identify the key 


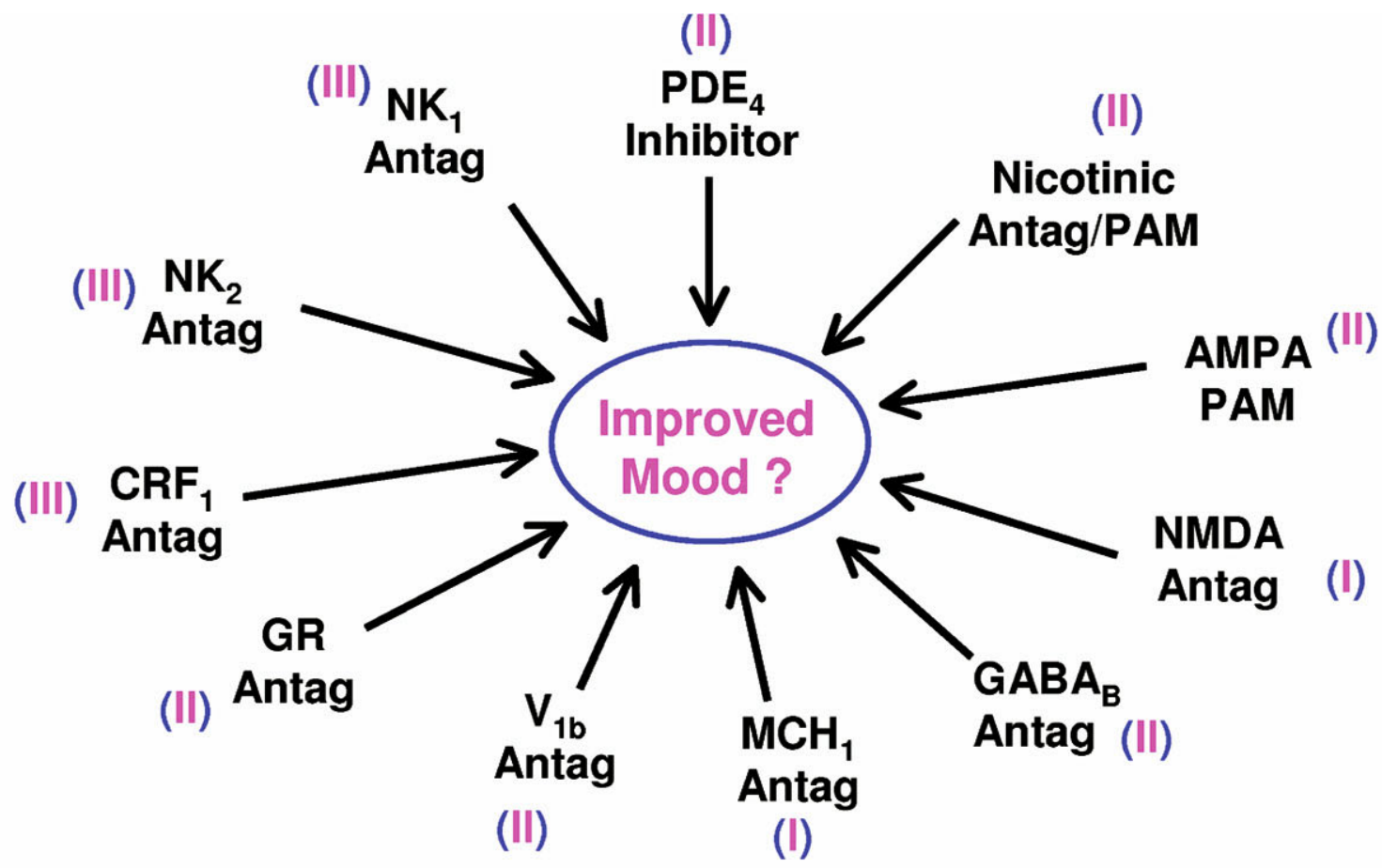

\section{Only selective $\left\{\begin{array}{c}\text { No drug has reached the market } \\ \text { No proof (yet) for } \uparrow \text { efficacy/ } \downarrow \text { delay }\end{array}\right\} \begin{gathered}\text { Complementary } \\ \text { multi-target }\end{gathered}$ drugs to date Uncertain control of co-morbid symptoms \\ multi-target strategies}

FIG. 1. Nonmonoaminergic mechanisms for treatment of major depression under clinical investigation with selective drugs. Numbers in Roman numerals refer to the highest phase of clinical development attained to date. Certain mechanisms are being evaluated for other indications, such as AMPA receptor facilitators, PDE-4 inhibitors, and nicotinic modulators for Alzheimer's disease. There is still no proof that selective drugs acting via such nonmonoaminergic mechanisms can robustly treat depression. Antag = antagonist; CRF = corticotrophin releasing factor; $\mathrm{GR}=$ glucocorticoid receptor; $\mathrm{MCH}=$ melanin concentrating hormone; $\mathrm{NK}=$ neurokinin; PAM = positive allosteric modulator; $\mathrm{PDE}=$ phosphodiesterase; $\mathrm{V}=$ vasopressin.

mechanisms of such treatments and transform them into more accessible multitarget agents-although this is unlikely to prove simple.

Sixth, suppression of the muscarinic and histamine $\mathrm{H}_{1}$ antagonist properties of tricyclic drugs, and elimination of their actions at cardiac ion channels, has led to the far safer SSRIs. ${ }^{3,7,31,32}$ Nonetheless, the belief that selective drugs are inherently better tolerated than equivalent multitarget agents is ill-founded. One familiar example is provided by selective cyclooxygenase- $2\left(\mathrm{COX}_{2}\right)$ inhibitors, which present greater problems of cardiovascular security than drugs with balanced actions relative to $\mathrm{COX}_{1} \cdot{ }^{33}$ Furthermore, dopamine $\mathrm{D}_{2}$ antagonists with marked 5- $\mathrm{HT}_{2 \mathrm{~A} / 2 \mathrm{C}}$ receptor antagonist properties have a lesser propensity to elicit an extrapyramidal syndrome. ${ }^{34}$ By analogy, 5-HT reuptake inhibitors with equilibrated antagonist properties at $5-\mathrm{HT}_{2 \mathrm{C}}$ sites should have tolerability superior to that of SSRIs, because certain of their undesirable actions, such as short-term anxiety, derive from stimulation of $5-\mathrm{HT}_{2 \mathrm{C}}$ sites (discussed later in this article).

In the search for dual-acting, triple-acting, and higher orders of multitarget agents, essentially three classes of ligand are of interest, from both a conceptual and a clinical perspective. First are drugs with exclusively monoaminergic targets, but mechanistically distinct from (and superior to) SSRIs, tricyclics, and other currently available classes of agent due to either or both 1) deletion of sites provoking adverse effects, and 2) incorporation of new targets underlying beneficial actions (FIG. 2). Second are drugs acting at combinations of nonmonoaminergic targets-although none have as yet been developed. Third, and most promising, are agents with a clinically validated monoaminergic mechanism, such as suppression of 5-HT reuptake or blockade of $5-\mathrm{HT}_{2 \mathrm{C}}$ receptors, plus a novel, nonmonoaminergic mechanism of action to refine the therapeutic profile (FIG. 3). 
Table 2. Multitarget and Network-Based Actions of Prototypical Drugs Used for Treating CNS Disorders

\begin{tabular}{|c|c|c|c|c|}
\hline Disorder & Class (Drug) & Principal Effects & Major Loci of Action & Adverse Effects \\
\hline Major depression & $\begin{array}{l}\text { Tricyclic } \\
\quad \text { (amitriptyline) }\end{array}$ & $\begin{array}{l}\text { 5-HT/NA reuptake } \\
\text { inhibition; } 5-\mathrm{HT}_{2 \mathrm{~A} / 2 \mathrm{C}} \\
\text { receptor blockade }\end{array}$ & $\begin{array}{l}\text { FCX; septum; } \\
\text { hippocampus }\end{array}$ & $\begin{array}{l}\text { Poor autonomic/CV } \\
\text { tolerability due to } \mathrm{H}_{1} / \\
\text { muscarinic blockade; } \\
\text { cardiotoxicity }\left(\mathrm{Na}^{+} /\right. \\
\mathrm{Ca}^{2+} \text { channels) }\end{array}$ \\
\hline Bipolar disorder & Ion (lithium) & $\begin{array}{l}\downarrow \text { IP production; } \\
\text { GSK-3 } \beta \text { inhibition*; } \\
\downarrow \text { glutamate release }\end{array}$ & $\begin{array}{l}\text { Cortex; hippocampus; } \\
\text { amygdala; thalamus }\end{array}$ & $\begin{array}{l}\text { Muscular weakness; } \\
\text { toxicity; hyperdipsia }\end{array}$ \\
\hline $\begin{array}{l}\text { Generalized anxiety } \\
\text { disorder }\end{array}$ & $\begin{array}{l}\text { Benzodiazepine } \\
\text { (clorazepate) }\end{array}$ & $\begin{array}{l}\mathrm{GABA}_{\mathrm{A}} \text { positive; } \\
\text { modulator, } \sim 17 \\
\text { subunits; }>100 \\
\text { subtypes }\end{array}$ & $\begin{array}{l}\text { Hippocampus; amygdala; } \\
\text { PAG; LC; DRN }\end{array}$ & $\begin{array}{l}\text { Sedation; alcohol } \\
\text { interaction; } \\
\text { dependence; tolerance }\end{array}$ \\
\hline Schizophrenia & Atypical (clozapine) & $\begin{array}{l}\mathrm{D}_{1}-\mathrm{D}_{5} ; 5-\mathrm{HT}_{1 \mathrm{~A} / 2 \mathrm{~A} / 2 \mathrm{C} / 6 / 7} \\
\text { and } \alpha_{1} / \alpha_{2}-\mathrm{AR} \\
\text { receptors; } \\
\text { GABAergic and } \\
\text { glutamate modulation }\end{array}$ & $\begin{array}{l}\text { FCX; nucleus accumbens; } \\
\text { hippocampus; thalamus }\end{array}$ & $\begin{array}{l}\text { Poor autonomic/CV } \\
\text { tolerability due to } \mathrm{H}_{1} / \\
\text { muscarinic blockade; } \\
\text { agranulocytosis } \\
\text { (structure-related); } \\
\text { seizures }\end{array}$ \\
\hline \multirow[t]{2}{*}{ Alzheimer's disease } & $\begin{array}{l}\text { Acetylcholinesterase } \\
\text { inhibitor } \\
\text { (galantamine) }\end{array}$ & $\begin{array}{l}\text { Nicotinic modulator; } \\
\text { butyrylcholinesterase } \\
\text { inhibitor; } \downarrow \beta- \\
\text { amyloid production }\end{array}$ & Cortex; hippocampus & $\begin{array}{l}\text { Poor tolerability; } \\
\text { (cholinergic adverse } \\
\text { effects) }\end{array}$ \\
\hline & $\begin{array}{l}\text { Noncompetitive } \\
\text { NMDA antagonist } \\
\text { (memantine) }\end{array}$ & $\begin{array}{l}\text { Rapid-kinetic NMDA } \\
\text { channel blocker; 5- } \\
\mathrm{HT}_{3} \text { antagonist; } \\
\text { nicotinic modulator }\end{array}$ & Cortex; hippocampus & $\begin{array}{l}\text { Overall mild; confusion; } \\
\text { tiredness; hallucinations }\end{array}$ \\
\hline Parkinson's disease & $\begin{array}{l}\text { DA precursor } \\
\text { (L-DOPA) }\end{array}$ & $\begin{array}{l}\uparrow \mathrm{DA} \text { recruits } \mathrm{D}_{1}-\mathrm{D}_{5} \\
\text { sites; serotonergic, } \\
\text { glutamatergic, and } \\
\text { other mechanisms }\end{array}$ & $\begin{array}{l}\text { Striatum; substantia nigra; } \\
\text { nucleus accumbens; } \\
\text { subthalamic nucleus; } \\
\text { FCX }\end{array}$ & Wearing-off; dyskinesia \\
\hline
\end{tabular}

Increases in levels of 5-HT, noradrenaline, DA, or acetylcholine will indirectly recruit multiple classes of serotonergic, adrenergic, dopaminergic, and nicotinic/muscarinic receptors, respectively. Autonomic and cardiovascular adverse effects mainly, but not only, reflect blockade of histaminergic $\left(\mathrm{H}_{1}\right)$ and muscarinic receptors.

$\mathrm{CV}=$ cardiovascular; DA $=$ dopamine; $\mathrm{DRN}=$ dorsal raphe nucleus; $\mathrm{FCX}=$ frontal cortex $; 5-\mathrm{HT}=$ serotonin; IP $=$ inositol phosphate; LC $=$ locus coeruleus; PAG $=$ periaqueductal gray area; $\uparrow(\downarrow)=$ increased (decreased).

*Indirect and direct.

\section{NOVEL DUAL- AND TRIPLE-ACTING MONOAMINERGIC ANTIDEPRESSANTS}

Return to the future: the promise of novel monoaminergic strategies

Reflecting the crucial role of monoamines in the control of mood, cognition, motor behavior, and other func- tions disrupted in depression, monoaminergic drugs remain the cornerstone of treatment, nearly 50 years after the discovery of tricyclics. ${ }^{3,7,35,36}$ The SSRIs and noradrenaline (NA) reuptake inhibitors (NARIs) are not more effective than tricyclic agents and, despite the (overall) more robust actions of mixed 5-HT/NA re-

Table 3. Multiple Mechanisms Involved in Actions of Somatic Antidepressant Interventions

\begin{tabular}{lcccccc}
\hline & $5-\mathrm{HT}$ & $\mathrm{NA}$ & $\mathrm{DA}$ & Opioid & Galanin & BDNF \\
\hline Tricyclic antidepressants & $\uparrow$ & $\uparrow$ & $\uparrow$ & $\uparrow$ & $\uparrow$ & $\uparrow$ \\
Sleep (REM) deprivation & $\uparrow$ & $\uparrow$ & $\uparrow$ & $\uparrow$ & $\uparrow$ & $\uparrow$ \\
Electroconvulsive therapy & $\uparrow$ & $\uparrow$ & $\uparrow *$ & $\uparrow$ & $\uparrow$ & $\uparrow$ \\
Vagal nerve stimulation & $\uparrow$ & $\uparrow$ & $\uparrow /-$ & $?$ & $?$ & $\uparrow$ \\
Transcranial magnetic stimulation & $\uparrow$ & $\uparrow /-$ & $\uparrow$ & $\uparrow$ & $?$ & $\uparrow$
\end{tabular}

Apart from endogenous opioid peptides and galanin, many other neuropeptides are variously affected by these treatments (e.g., substance P, neuropeptide $\mathrm{Y}$, corticotrophin releasing factor, and vasopressin). Many corticolimbic structures are affected, as revealed by imaging studies discussed in the text. For more details, see Millan, 2006. ${ }^{3}$

$\mathrm{BDNF}=$ brain-derived neurotrophic factor (serum levels in patents); DA = dopamine; NA = noradrenaline; REM = rapid eye movement; $?=$ little concrete information is available.

*Increased transmission at postsynaptic level. 

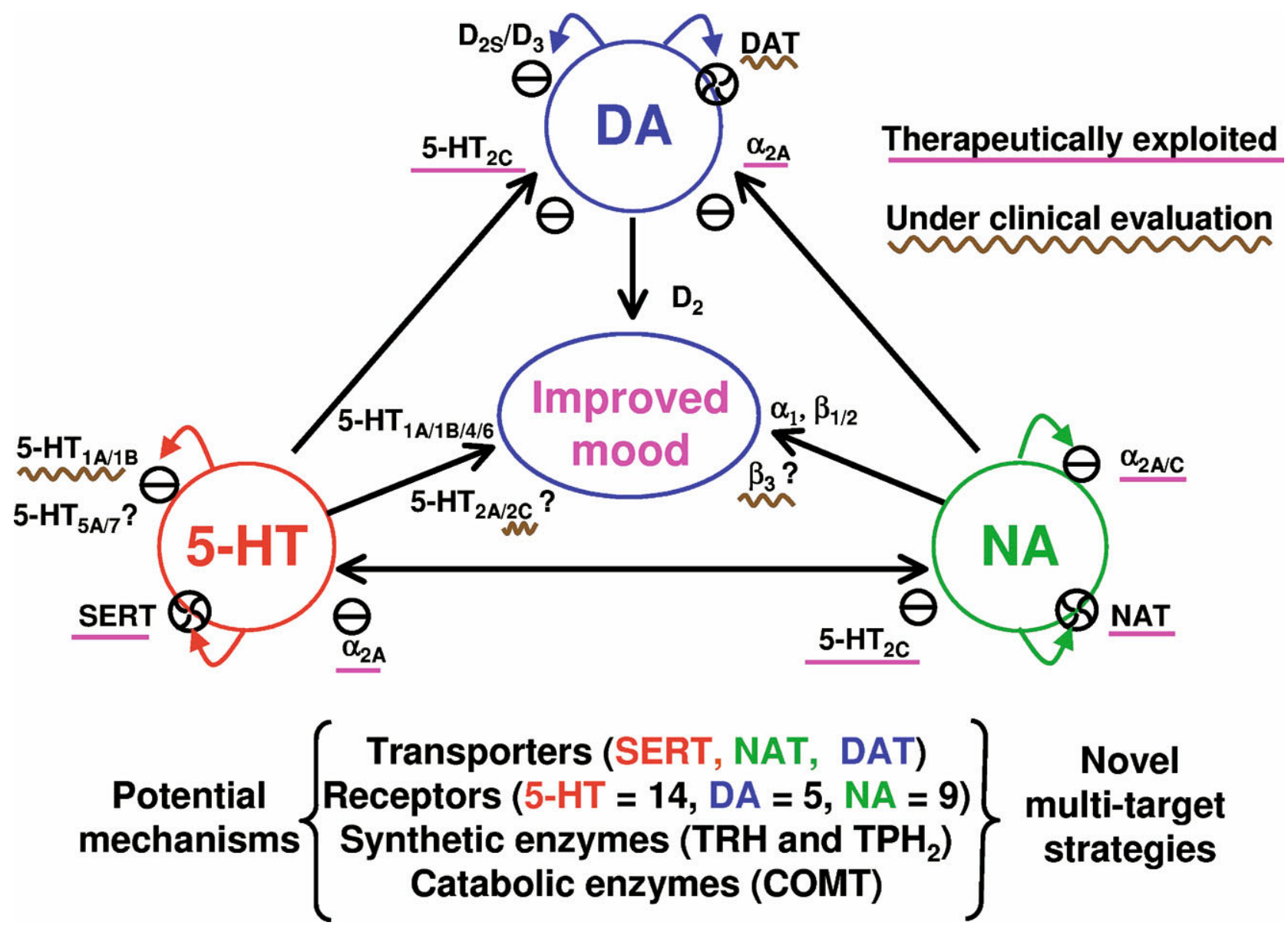

FIG. 2. Monoaminergic strategies for improving the management of depression: scope for further exploitation. Interacting monoaminergic pathways control mood, and their perturbation contributes to the induction of depression. Antidepressants in clinical use act principally by inhibiting monoamine oxidase (not shown), or by suppressing reuptake of either or both 5-HT and NA or by blocking $5-\mathrm{HT}_{2 \mathrm{C}} / \alpha_{2}$-adrenergic receptors, or by both reuptake inhibition and receptor blocking mechanisms. Unexploited opportunities remain for acting at diverse monoaminergic receptors; TRH, which generates NA and DA; $\mathrm{TPH}_{2}$, which yields 5-HT; COMT, which catabolizes DA; and DAT. COMT = catecholamine methyl transferase; DA = dopamine; DAT = dopamine transporter; 5-HT = serotonin; NA = noradrenaline; NAT $=$ noradrenaline transporter; SERT = serotonin transporter; TRH = tyrosine hydroxylase; TPH $=$ tryptophan hydroxylase.

uptake inhibitors (SNRIs) such as venlafaxine versus SSRIs and NARIs, no advantage in efficacy has been achieved relative to tricyclics. ${ }^{2,3,37,38}$ Nonetheless, it would be premature to abandon monoaminergic mechanisms: several novel targets and mechanisms of potential importance remain to be clinically exploited (Table 4 and FIG. 2).

\section{Triple inhibitors of monoamine reuptake}

Currently used antidepressants generally interfere with transporter-mediated reuptake of 5-HT, NA, or both. Moreover, mainly due to actions at NA transporters, which control the levels of dopamine (DA) in the frontal cortex, they likewise reinforce frontocortical dopaminergic transmission. ${ }^{3,39,40}$ Notably, without affecting extracellular levels of DA, sustained administration of diverse antidepressants and electroconvulsive therapy enhances transmission at dopaminergic receptors in the nucleus accumbens. $^{2,3,41}$ A generalized and rapid strengthen- ing of dopaminergic transmission could otherwise be achieved by direct blockade of DA transporters, which are enriched in mesolimbic structures. ${ }^{40}$ This is important, because a dysfunction of dopaminergic mechanisms of reward is incriminated in anhedonia. ${ }^{41}$ Moreover, suppression of DA reuptake enhances sexual function and may improve cognitive performance. ${ }^{3,42,43}$ Finally, the DA reuptake inhibitor (DARI) bupropion enhances the antidepressant actions of SSRIs in rodents and in humans ${ }^{44,45}$ so it is worth asking how antidepressants that interact with DA transporters in addition to 5-HT or NA transporters (or both) compare with associations of DA reuptake inhibitors and SSRIs and SNRIs (further discussed later in this review).

Based on this reasoning, and in view of the relative simplicity of designing drugs that inhibit DA reuptake, there is much current interest in triple inhibitors of 5-HT, NA, and DA reuptake that express antidepressant actions 


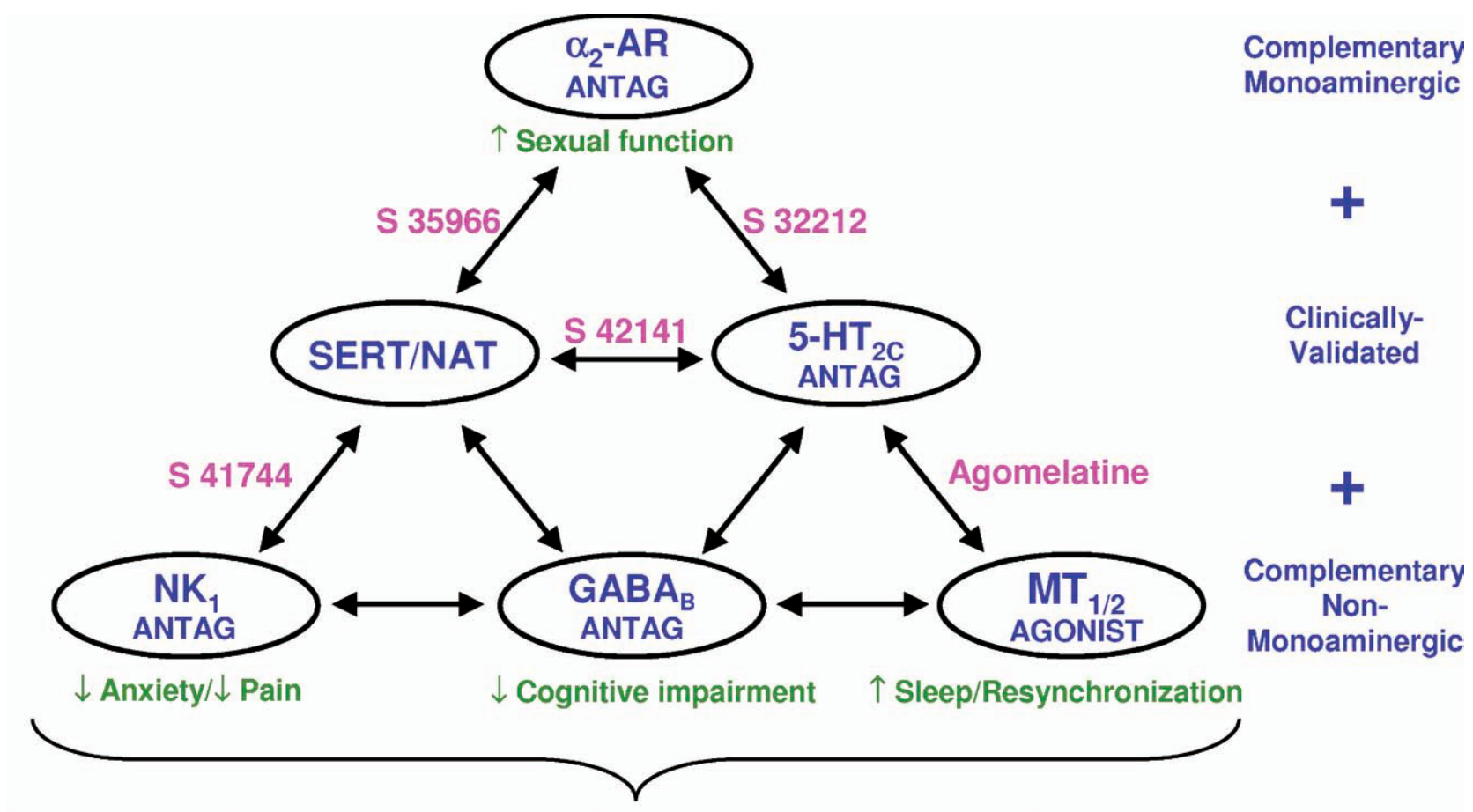

\section{$\uparrow$ EFFICACY, $\downarrow$ ONSET OF ACTION, $\downarrow$ CO-MORBID SYMPTOMS, $\uparrow$ TOLERANCE}

FIG. 3. A matrix of dual-acting agents for the improved treatment of major depression. One compelling strategy for improved drugs is to retain a clinically validated monoaminergic substrate of antidepressant activity and to build in complementary mechanisms: for example, additional monoaminergic actions such as blockade of $\alpha_{2}$-adrenoceptors. A vast range of nonmonoaminergic targets could

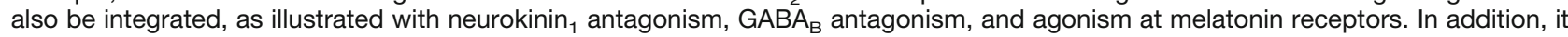
is theoretically possible to unite nonmonoaminergic mechanisms. Examples of bimodal monoaminergic/nonmonoaminergic antidepressants under study in the author's laboratory are given. Antag = antagonist; AR = adrenoceptor; 5-HT = serotonin; MT = melatonin; NAT = noradrenaline transporter; NK = neurokinin; SERT = serotonin transporter.

in behavioral models (FIG. 4). ${ }^{46-51}$ In addition to possible autonomic and cardiovascular adverse effects, a concern with drugs blocking (mesolimbic) DA reuptake is their potential for abuse and likelihood of dependency. Nonetheless, the kinetics of elevation in DA levels is the key question, and drugs with slow rates of DA rise may be acceptable. ${ }^{52,53}$ Initial experimental data are in line with this optimism, although rigorous clinical feedback is yet to come. It can be hoped that triple inhibitors will prove to have acceptable abuse and dependence potential and will offer improved efficacy in the management of depression - and perhaps also of other disorders, such as Parkinson's disease. ${ }^{54}$

\section{Agents blocking both 5-HT reuptake and inhibitory 5-HT autoreceptors}

Encouraging findings with adjunctive use of pindolol, a $\beta$-adrenoceptor (AR) partial agonist with $5-\mathrm{HT}_{1 \mathrm{~A} / 1 \mathrm{~B}}$ antagonist properties, prompted the search for drugs behaving as either $5-\mathrm{HT}_{1 \mathrm{~A}}$ antagonist/SRIs or $5-\mathrm{HT}_{1 \mathrm{~B}}$ antagonists/SRIs (FIG. 5). ${ }^{3,40,55-57}$ Although clinical confirmation is still pending, they can be expected to mimic the downregulation of $5-\mathrm{HT}_{1 \mathrm{~A} / 1 \mathrm{~B}}$ autoreceptors seen upon long-term exposure to SSRIs, thereby relieving negative feedback and enhancing speed to efficacy. ${ }^{58-61}$
However, few 5-HT $\mathrm{HB}_{1 \mathrm{~B}}$ antagonists/SRIs have seen the light of day, and mixed 5- $\mathrm{HT}_{1 \mathrm{~A}}$ antagonists/SRIs await comprehensive characterization in vivo. ${ }^{5,57,62,63}$ Several $5-\mathrm{HT}_{1 \mathrm{~A}}$ partial agonists with SRI properties have been described (FIG. 5), but despite evidence of 1) antidepressant actions in rodents, 2) enhancement of frontocortical levels of DA and NA, and 3) a postulated rapid desensitization of $5-\mathrm{HT}_{1 \mathrm{~A}}$ autoreceptors, they are expected to blunt increases in 5-HT levels by SSRIs. ${ }^{40,64}$ Indeed, clinical data on vilazodone (still in Phase III trials) have been disappointing. ${ }^{65}$ Moreover, other agents such as EMD-95750 appear to have been dropped, and OPC14523 - which also recognizes $\sigma_{1}$-sites-has been shunted toward other indications, such as sexual dysfunction. ${ }^{66,67}$

A complementary approach consists of the generation of drugs acting as pan-autoreceptor antagonists that block 5- $\mathrm{HT}_{1 \mathrm{~A}}, 5-\mathrm{HT}_{1 \mathrm{~B}}$, and related 5-HT $\mathrm{HD}_{1 \mathrm{D}}$ sites, which also have a minor presynaptic role (FIG. 5). ${ }^{40,58,68}$ Such a triple-acting antagonist (or inverse agonist) might increase serotonergic transmission and display antidepressant effects in the absence of SRI properties-although this is a long shot, and such agents appear (at least for now) to be mainly of academic interest. ${ }^{69,70}$ By contrast, 
Table 4. Comparison of Some Novel Bimodal and Trimodal Antidepressant Strategies under Evaluation

\begin{tabular}{|c|c|c|c|c|}
\hline Concept & $\begin{array}{l}\text { Examples of } \\
\text { Drugs }\end{array}$ & Clinical Aspects & Potential Advantages & Possible Drawbacks \\
\hline $\begin{array}{l}\text { Triple inhibition of } \\
\text { 5-HT/NA/DA reuptake }\end{array}$ & $\begin{array}{l}\text { SEP 225,289; } \\
\text { GSK } 372,475\end{array}$ & $\begin{array}{l}\text { Trials underway in } \\
\text { major depression } \\
\text { (and Parkinson's } \\
\text { disease) }\end{array}$ & $\begin{array}{l}\text { Improved efficacy, especially } \\
v s \text { anhedonia; improved } \\
\text { sexual function }\end{array}$ & $\begin{array}{l}\text { Risk of dependence, } \\
\text { abuse, psychosis }\end{array}$ \\
\hline $\begin{array}{l}\text { SRI and/or NA reuptake } \\
\text { inhibition plus } \alpha_{2}-\mathrm{AR} \\
\text { antagonism }\end{array}$ & $\begin{array}{l}\text { S 39566; R } \\
226121\end{array}$ & $\begin{array}{l}\text { The } \alpha_{2} \text {-AR antagonist, } \\
\text { yohimbine, enhanced } \\
\text { clinical effectiveness } \\
\text { of fluoxetine }\end{array}$ & $\begin{array}{l}\text { Improved efficacy; faster } \\
\text { onset; improved cognition } \\
\text { and sexual function }\end{array}$ & $\begin{array}{l}\text { Adverse cardiovascular } \\
\text { effects (increased } \\
\text { arterial pressure and } \\
\text { tachycardia) }\end{array}$ \\
\hline $\begin{array}{l}\text { SRI plus histamine } \mathrm{H}_{3} \\
\text { antagonism }\end{array}$ & JNJ 28583867 & $\begin{array}{l}\text { Selective } \mathrm{H}_{3} \\
\text { antagonists under } \\
\text { evaluation in } \\
\text { Alzheimer's disease }\end{array}$ & $\begin{array}{l}\text { Improved cognitive function; } \\
\text { low risk of obesity }\end{array}$ & Poor sleep \\
\hline $\begin{array}{l}\text { SRI plus AMPA } \\
\text { receptor facilitation }\end{array}$ & $\begin{array}{l}\text { LY 392,098; LY } \\
\quad 404,187^{*}\end{array}$ & $\begin{array}{l}\text { Selective ampakines } \\
\text { under study for } \\
\text { cognition }\end{array}$ & $\begin{array}{l}\text { Improved efficacy; enhanced } \\
\text { neuronal resilience; } \\
\text { improved cognition; } \\
\text { resynchronization }\end{array}$ & $\begin{array}{l}\text { Neurotoxicity, sensory } \\
\text { disruption }\end{array}$ \\
\hline $\begin{array}{l}\text { SRI plus } \mathrm{NK}_{1} \\
\text { antagonism }\end{array}$ & GSK 424,887 & $\begin{array}{l}\text { Vestipitant }\left(\mathrm{NK}_{1}\right. \\
\text { antagonist) }+ \\
\text { paroxetine (SSRI) } \\
\text { under study }\end{array}$ & $\begin{array}{l}\text { Improved efficacy; faster } \\
\text { onset; control of somatic } \\
\text { symptoms (nausea and } \\
\text { pain) and of anxiety }\end{array}$ & $\begin{array}{l}\text { Unclear (but less } \\
\text { marked than for } \\
\text { SSRIs) }\end{array}$ \\
\hline $\begin{array}{l}\text { SRI plus } \mathrm{GR} \text { or } \mathrm{CRF}_{1} \\
\text { antagonism }\end{array}$ & None described & $\begin{array}{l}\text { Selective GR and } \\
\text { CRF }_{1} \text { antagonists } \\
\text { under evaluation in } \\
\text { psychotic depression }\end{array}$ & $\begin{array}{l}\text { Increased efficacy (psychotic } \\
\text { depression); enhanced } \\
\text { resistance to stress; } \\
\text { anxiolytic properties } \\
\left(\mathrm{CRF}_{1}\right)\end{array}$ & $\begin{array}{l}\text { Excessive blockade of } \\
\text { favorable actions of } \\
\text { glucocorticoids/HPA } \\
\text { axis }\end{array}$ \\
\hline $\begin{array}{l}\text { Melatonin agonism plus } \\
5-\mathrm{HT}_{2 \mathrm{C}} \text { antagonism }\end{array}$ & Agomelatine & $\begin{array}{l}\text { Proven short and long- } \\
\text { term efficacy in } \\
\text { major depression; } \\
\text { effective in GAD }\end{array}$ & $\begin{array}{l}\text { Diurnal resynchronization; } \\
\text { improved sleep; lack of } \\
\text { SSRI adverse effects }\end{array}$ & $\begin{array}{l}\text { Few adverse effects } \\
\text { overall, and mild; } \\
\text { dizziness }\end{array}$ \\
\hline $\begin{array}{l}\text { SRI plus GSK-3 } \beta \\
\text { inhibition }\end{array}$ & None described & $\begin{array}{l}\text { Lithium (GSK-3 } \beta \\
\text { inhibitor) enhances } \\
\text { antidepressant } \\
\text { efficacy of SSRIs. }\end{array}$ & $\begin{array}{l}\text { Improved efficacy, enhanced } \\
\text { neuronal resilience }\end{array}$ & $\begin{array}{l}\text { Widespread CNS and } \\
\text { peripheral nervous } \\
\text { system effects } \\
\text { (including metabolic) }\end{array}$ \\
\hline
\end{tabular}

5-HT = serotonin $; \mathrm{CRF}_{1}=$ corticotrophin releasing factor ${ }_{1} ; \mathrm{DA}=$ dopamine; $\mathrm{GAD}=$ generalized anxiety disorder; $\mathrm{GR}=$ glucocorticoid; GSK- $3 \beta=$ glycogen synthase kinase- $3 \beta ; \mathrm{HPA}=$ hypothalamo-pituitary-adrenocortical; $\mathrm{NA}=$ noradrenaline $\mathrm{NK}_{1}=$ neurokinin $_{1} ; \mathrm{SRI}^{2}$ serotonin reuptake inhibition; SSRI $=$ selective serotonin reuptake inhibitor.

*Bind (modestly) to 5-HT transporters.

SB-649915-B behaves as a mixed 5-HT $1 \mathrm{~A} / 1 \mathrm{~B}$ antagonist/ SRI, with a more rapid onset of anxiolytic properties than with SSRIs (FIG. 5). ${ }^{71-73}$ Its putative antidepressant profile remains uncertain and, like the ligands already discussed, SB-649915-B blocks postsynaptic 5-HT ${ }_{1 \mathrm{~A}}$ and $5-\mathrm{HT}_{1 \mathrm{~B}}$ sites-which, rather awkwardly, may participate in the mood-improving actions of SSRIs. ${ }^{3}$ Possibly, other components of depressive states such as cognitive deficits and sexual dysfunction will be improved by this intriguing drug. ${ }^{3,42,60,74,75}$

Although findings are less well established than for $5-\mathrm{HT}_{1 \mathrm{~A}}$ and $5-\mathrm{HT}_{1 \mathrm{~B}}$ autoreceptors, $5-\mathrm{HT}_{7}$ receptors may also be inhibitory to serotonergic transmission. Accordingly, 5- $\mathrm{HT}_{7}$ antagonists enhance the actions of SSRIs and alone elicit modest antidepressant and anxiolytic effects in rodents. ${ }^{76-79}$ Furthermore, mimicking SSRIs, genetic deletion of 5- $\mathrm{HT}_{7}$ receptors suppresses rapid eye movement sleep. ${ }^{80}$ Although the interrelationship be- tween sleep and mood is the subject of debate, antagonism of $5-\mathrm{HT}_{7}$ receptors in the suprachiasmatic nucleus modifies circadian rhythms, which are deregulated in depression. ${ }^{3,79,81,82}$ Hence, bimodal 5-HT 7 antagonists/ SRIs are of interest. The $5-\mathrm{HT}_{5 \mathrm{~A}}$ receptors may also be inhibitory to serotonergic transmission, and $5-\mathrm{HT}_{5 \mathrm{~A}}$ sites in the suprachiasmatic nucleus also control circadian rhythms. ${ }^{83}$ The recent description of selective $5-\mathrm{HT}_{5 \mathrm{~A}}$ antagonists, which enhanced frontocortical levels of 5-HT in the presence of 5-HT $1 \mathrm{~A}$ receptor blockade, will allow for exploration of the potential interest of mixed $5-\mathrm{HT}_{5 \mathrm{~A}}$ antagonists/SRIs. ${ }^{84}$

\section{Bimodal antidepressants acting as $5-\mathrm{HT}_{2 \mathrm{C}}$ or $5-\mathrm{HT}_{2 \mathrm{~A}}$ receptor antagonists}

Blockade of excitatory $5-\mathrm{HT}_{2 \mathrm{C}}$ sites on GABAergic interneurons inhibitory to raphe cell bodies indirectly enhances the influence of SSRIs on levels of 5-HT in 
<smiles>CN(C)CC(c1ccc(O)cc1)C1(O)CCCCC1</smiles>

DES-VENLAFAXINE (SNRI)<smiles>Clc1ccc([C@]23CNC[C@H]2C3)cc1Cl</smiles>

DOV-21947 ((+) DOV-216303) (SNDRI)<smiles>C[C@H]1NC(C)(C)CC[C@]1(O)c1cccc(Cl)c1</smiles><smiles>CN(C)C[C@H](O)[C@H](O)c1ccc2ccccc2c1</smiles>

RADAFAXINE (DNRI)

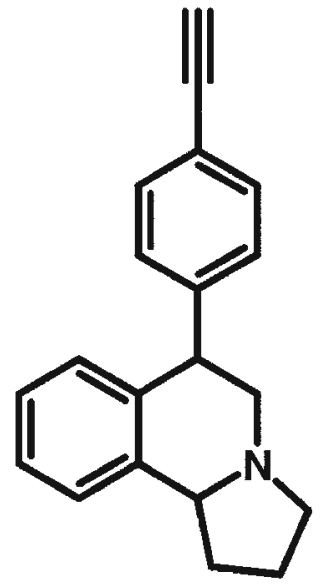

JNJ-7925476 (SNDRI)

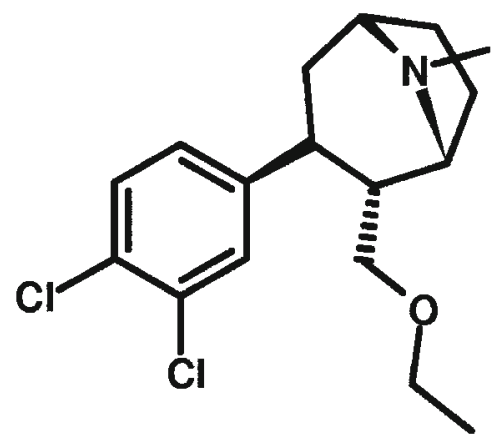

TESOFENSINE (NS2330) (SNDRI)

FIG. 4. Chemical structures of drugs interacting with various combinations of monoamine transporters. The 5-HT/NA reuptake inhibitor, des-venlafaxine, is an active metabolite of venlafaxine, while radafaxine (which suppresses transport of DA and NA) is an active (4-hydroxy) metabolite of the preferential DA reuptake inhibitor bupropion. PRC025 and DOV-21947 inhibit reuptake of 5-HT, NA and DA (SNDRI). The same holds for JNJ-7925476 and tesofensine, the latter of which is also oriented toward Parkinson's disease. Antag = antagonist; $\mathrm{DA}=$ dopamine; 5-HT = serotonin; NA = noradrenaline; DNRI = dopamine and noradrenaline reuptake inhibitor; SNDRI $=$ serotonin, dopamine, and noradrenaline reuptake inhibitor.

frontal cortex and hippocampus. ${ }^{85-87}$ In addition, blockade of ventrotegmental- and locus ceruleus-localized $5-\mathrm{HT}_{2 \mathrm{C}}$ sites disinhibits dopaminergic and adrenergic pathways, respectively, and $5-\mathrm{HT}_{2 \mathrm{C}}$ antagonists elicit robust antidepressant and anxiolytic actions in a broad range of paradigms. ${ }^{40,85,86,88-90}$ Blockade of $5-\mathrm{HT}_{2 \mathrm{C}}$ sites may, further, enhance sexual function and improve restorative slow wave sleep, ${ }^{42,85,91}$ and antagonism of hypothalamic 5- $\mathrm{HT}_{2 \mathrm{C}}$ receptors facilitatory to the hypothalamo-pituitary-adrenocortical (HPA) axis abrogates its overstimulation by stress. ${ }^{88}$

Underpinning interest in drugs that both block $5-\mathrm{HT}_{2 \mathrm{C}}$ sites and suppress 5-HT reuptake is the fact that, in addition to mediating anxiogenic actions, $5-\mathrm{HT}_{2 \mathrm{C}}$ receptors are the principal culprits transducing the disruption of sleep, sexual function, and appetite by SSRIs. ${ }^{3,85,90-93}$ Nefazodone has a $5-\mathrm{HT}_{2 \mathrm{C}}$ antagonist/SRI profile but its blockade of $\mathrm{H}_{1}$ receptors provokes sedation. Further- more, nefazodone was found to be metabolically unstable and was withdrawn for concerns of hepatic safety, and similar drugs (e.g., YM-992) do not appear to have been pursued. ${ }^{3,63}$ One attractive prospect would be a triple-acting $5-\mathrm{HT}_{2 \mathrm{C}}$ receptor antagonist/SNRI corresponding to the core mechanism of tricyclic agents (but, obviously, shorn of their off-target effects at $\mathrm{H}_{1}$ sites, muscarinic receptors, and cardiac ion channels) (FIG. 3).

Multitarget exploitation of $5-\mathrm{HT}_{2 \mathrm{C}}$ receptor antagonism need not be confined to suppression of monoamine reuptake. A further promising avenue is represented by the urea derivative, S32212 (FIG. 6), ${ }^{94,95}$ which has potent and balanced antagonist activity at $5-\mathrm{HT}_{2 \mathrm{C}}$ and $\alpha_{2}$-AR receptors and yet is devoid of affinity for $\mathrm{H}_{1}$ receptors-distinguishing it from the tetracyclic mirtazapine, which elicits somnolence and obesity. ${ }^{39,96-98}$ Integration of antagonist actions at $\alpha_{2}$-ARs is of significance, because their blockade potentiates monoaminergic trans- 


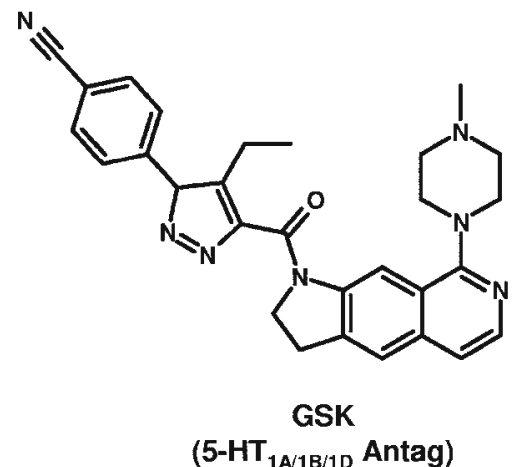

$\left(5-\mathrm{HT}_{1 \mathrm{~A} / 1 \mathrm{~B} / 1 \mathrm{D}}\right.$ Antag)

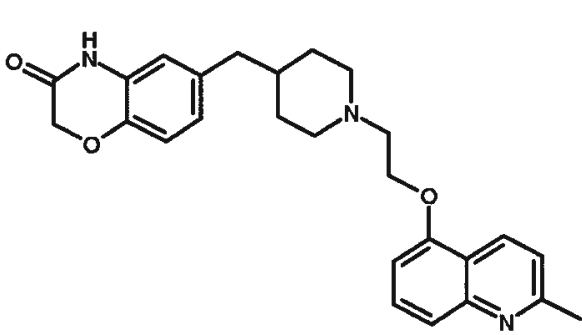

SB 649,915

$\left(5-\mathrm{HT}_{1 \mathrm{~A} / 1 \mathrm{~B} / 1 \mathrm{D}}\right.$ Antag/SRI)

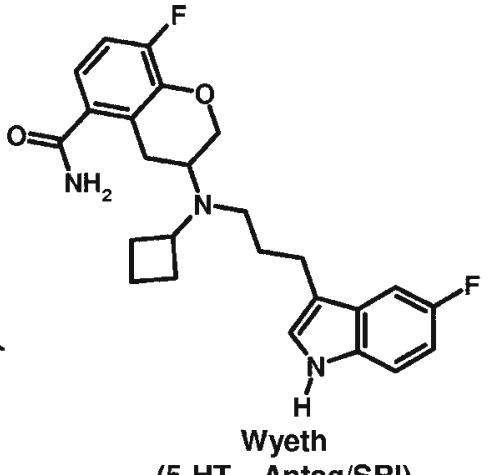

(5-HT ${ }_{1 \mathrm{~A}}$ Antag/SRI)
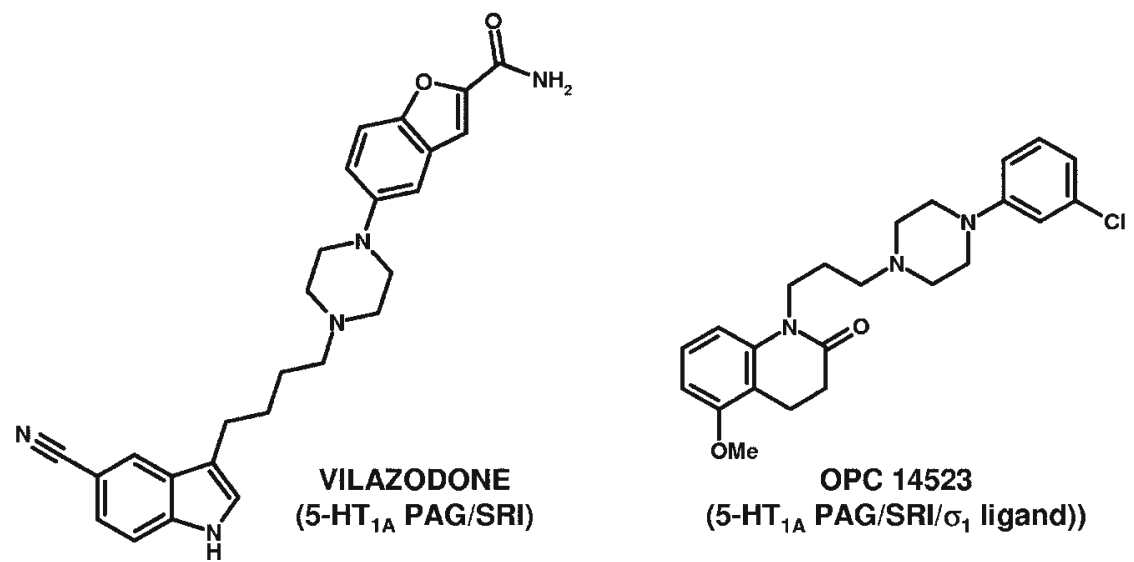

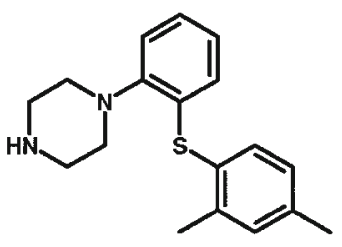

LU AA21004

(5- $\mathrm{HT}_{1 \mathrm{~A}} \mathrm{Ago} / 5-\mathrm{HT}_{3}$ Antag/SRI)

FIG. 5. Chemical structures of drugs acting at 5-HT autoreceptors inhibitory to serotonergic pathways, and with 5-HT transporters (SRI). A structure described by GSK behaves as a pan-antagonist at all classes of inhibitory 5-HT autoreceptor, although it does not bind to $5-\mathrm{HT}$ transporters. Wyeth described a mixed 5- $\mathrm{HT}_{1 \mathrm{~A}}$ antagonist/SRI (patent). SB 649,915 suppresses 5-HT reuptake and blocks $5-\mathrm{HT}_{1 \mathrm{~A}}, 5-\mathrm{HT}_{1 \mathrm{~B}}$, and 5- $\mathrm{HT}_{1 \mathrm{D}}$ autoreceptors. Vilazodone suppresses $5-\mathrm{HT}$ reuptake and is a partial agonist at 5- $\mathrm{HT}_{1 \mathrm{~A}}$ receptors. OPC 14523 and LU AA21004 share these properties, but also interact, respectively, with $\sigma_{1}$ binding sites and 5- $\mathrm{HT}_{3}$ receptors. Ago = agonist; Antag = antagonist; GSK = GlaxoSmithKline; $5-\mathrm{HT}=$ serotonin; $\mathrm{N}=$ noradrenaline; PAG = periaqueductal gray area; SRI = serotonin reuptake inhibitor.

mission and is associated with modest antidepressant actions, as well as a beneficial influence on sexual behavior and certain components of cognitive function. ${ }^{40,99-101}$ S32212 manifests antidepressant and anxiolytic properties in rodent models, and enhances cognition performance in some (but not all) procedures. ${ }^{94,95}$

Multitarget antidepressants homing into 5- $\mathrm{HT}_{2 \mathrm{C}}$ receptors agents may also profit from blockade of $5-\mathrm{HT}_{2 \mathrm{~A}}$ receptors, which blunts the disruption of hippocampal neurogenesis by stress and attenuates HPA axis overdrive. ${ }^{3,58,102}$ Finally, antihallucinogenic properties of $5-\mathrm{HT}_{2 \mathrm{~A}}$ antagonists may be pertinent to the control of psychotic depression. ${ }^{58,103}$

\section{Novel antidepressants with antagonist properties at 5-HT 3 receptors}

Selective $5-\mathrm{HT}_{3}$ receptor antagonists are clinically important in the treatment of nausea, a prominent early adverse effect of SSRIs that may involve stimulation of peripheral $5-\mathrm{HT}_{3}$ receptors. ${ }^{104,105}$ Furthermore, they exert modest antidepressant and anxiolytic effects in experimental procedures, and in an animal model ondansetron enhanced actions of SSRIs and SNRIs in a forced-swim test. ${ }^{105-107}$ Accordingly, drugs with $5-\mathrm{HT}_{3}$ antagonist/SRI properties have attracted interest. Although litoxetine has disappeared from clinical databases, the recently disclosed triple-profile agent, Lu- AA-21004 (FIG. 5), which is a $5-\mathrm{HT}_{3}$ antagonist/5- $\mathrm{HT}_{1 \mathrm{~A}}$ agonist/SRI, is in Phase III trials for treatment of major depression. ${ }^{108}$

\section{Recruiting subsets of postsynaptic sites mediating beneficial actions of antidepressants}

The identity of receptors implicated in the undesirable effects of monoaminergic antidepressants are fairly well known. ${ }^{3,32}$ The 5- $\mathrm{HT}_{2 \mathrm{C}}$ (and 5- $\mathrm{HT}_{2 \mathrm{~A}}$ ) receptors contribute to the acute anxiogenic actions of SSRIs and to their inhibitory influence on sleep, sexual function, and appetite; the 5- $\mathrm{HT}_{3}$ receptors are involved in the gastrointestinal effects and induction of nausea (see above). Stimulation of $\mathrm{D}_{2}$ receptors can provoke nausea and hypotension, whereas $\mathrm{D}_{3}$ receptors exert a negative influence on cognition, ${ }^{32,34,109}$ and activation of $\alpha_{1}$-ARs and $\beta_{1} / \beta_{2}$-ARs may perturb cardiovascular function. ${ }^{32}$

Somewhat paradoxically, although $\mathrm{D}_{2}$ receptors transduce the positive influence of DA on mood, and 


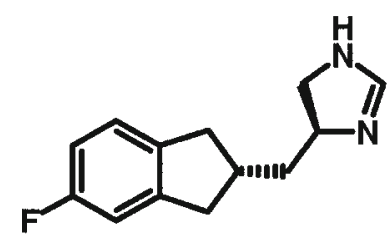

S 35966 ( $\alpha_{2}$-AR Antag/SNRI)<smiles>COc1cc2c(cc1OC)C1=NOC(CN3CCN(C/C(C)=C/c4ccc(F)cc4)CC3)C1CO2</smiles><smiles>COc1ccc(NC(=O)N2CCc3c2ccc2ccccc32)cc1N1CCN(C)CC1</smiles>

S 32212 $\left(\alpha_{2}-\mathrm{AR} / 5-\mathrm{HT}_{2 \mathrm{C} / 2 \mathrm{~A}}\right.$ Antag)<smiles>CSc1ccc([C@H]2CN(C)Cc3cc(OCCCN4CCOCC4)ccc32)cc1</smiles>

JNJ 28583867 ( $\mathrm{H}_{3}$ Antag/SRI)

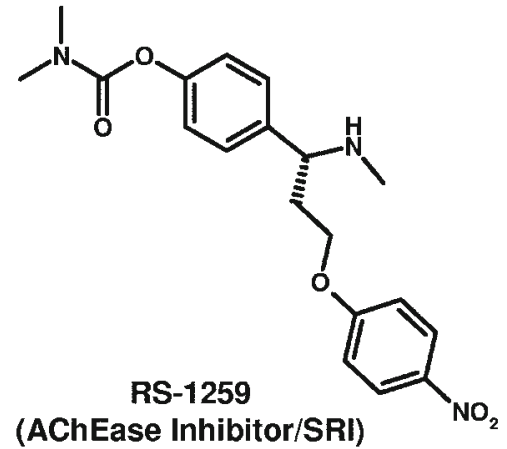

(AChEase Inhibitor/SRI)

FIG. 6. Chemical structures of drugs acting at 5-HT transporters (SRI) and at various sites influencing cognition. S 35966 and R-226161 are antagonists at $\alpha_{2}$-adrenoceptors and block the reuptake of 5-HT/NA and 5-HT, respectively. JNJ 28583867 is a mixed ligand of 5-HT transporters and Histamine $\mathrm{H}_{3}$ receptors. RS-1259 blocks 5-HT reuptake and the activity of acetylcholinesterase. S 32212 is an antagonist at $\alpha_{2}-\mathrm{AR}$ and $5-\mathrm{HT}_{2 \mathrm{C} / 2 \mathrm{~A}}$ receptors. Antag = antagonist; $\mathrm{AR}=$ adrenoceptor; $\mathrm{H}=$ histamine receptor; $\mathrm{NA}=$ noradrenaline; $\mathrm{SRI}=$ serotonin reuptake inhibitor; SNRI = serotonin and noradrenaline reuptake inhibitor.

$\mathrm{D}_{1} / \mathrm{D}_{5}$ receptors facilitate cognition, mechanisms mediating the beneficial effects of NA and 5-HT in depression remain uncertain. . $^{3,41,43,110,111} \alpha_{1}$-ARs may well participate in the positive influence of NA on mood and cognition. ${ }^{3,112}$ The $\beta_{1}$ and $\beta_{2}$-ARs are also involved. ${ }^{113}$ Curiously, an agonist at $\beta_{3}$ receptors (essentially absent from healthy adult human brain, although data for depressed tissue do not appear to be available) was in development for depression, but was recently discontinued. ${ }^{114,115}$

As regards 5-HT, the traditional candidates are $5-\mathrm{HT}_{1 \mathrm{~A}}$ receptors. This has never been clinically proven, not least owing to poor tolerability of agonists. ${ }^{3,32}$. Ligands acting via specific $5-\mathrm{HT}_{1 \mathrm{~A}}$-recruited signaling pathways may offer the hope of future clinical exploitation. ${ }^{68,116}$ $5-\mathrm{HT}_{1 \mathrm{~B}}$ receptors have also been forwarded as mediators of antidepressant actions of SSRIs, together with $5-\mathrm{HT}_{2 \mathrm{~A}}$ and (controversially) $5-\mathrm{HT}_{2 \mathrm{C}}$ and $5-\mathrm{HT}_{6}$ sites; $5-\mathrm{HT}_{4}$ receptors were also recently added to the inventory of potential serotonergic mechanisms for improving mood. ${ }^{3,58,86,117-119}$

No single receptor can account for the global therapeutic influence of antidepressants that increase monoamine levels. For example, cellular substrates controlling neurogenesis in the hippocampus differ from those that counter anhedonia. Monoaminergic antidepressants act, then, in a multitarget fashion. Once we have a better idea of exactly which postsynaptic sites genuinely contribute to, or interfere with, their favorable effects, it may be possible to conjure up dual- or triple-acting drugs acting via optimized subsets of receptors. In this regard at least, selective agents have an indispensable role in discerning the functional significance of individual classes of monoaminergic receptor. 


\section{Dual $\alpha_{2}$-AR autoreceptor antagonists/monoamine reuptake inhibitors}

Tonically active, inhibitory $\alpha_{2}$-AR autoreceptors are found on the perikarya and terminals of adrenergic pathways, and $\alpha_{2}$-AR heteroceptors are localized on terminals of corticolimbic serotonergic pathways and mesocortical dopaminergic fibers projecting to the frontal cortex..$^{40,100}$ Accordingly, the actions of antidepressants that increase extracellular levels of NA may be blunted by their indirect recruitment of presynaptic $\alpha_{2}$-ARs, and gradual desensitization of $\alpha_{2}$-AR autoreceptors is likely related to the delay to full efficacy. ${ }^{36,40,100,120}$ Although not all data support this notion, ${ }^{121}$ antagonism of $\alpha_{2}$-ARs consistently enhances the induction of extracellular levels of monoamines by antidepressants. ${ }^{40,100}$ This suggests that drugs that both block $\alpha_{2}$-ARs and suppress 5-HT and/or NA reuptake may be powerful and rapidly active antidepressants (FIG. 6). Indeed, although $\alpha_{2}$-AR antagonists display only weak, variable, and clinically trivial antidepressant properties, concomitant administration of yohimbine accelerated the therapeutic actions of fluoxetine. ${ }^{122}$ Underpinning interest in agents with $\alpha_{2}$-AR antagonist properties is the fact that blockade of inhibitory $\alpha_{2}$-ARs on cholinergic terminals in frontal cortex potentiates both acetylcholine release and some (but not all) aspects of cognitive performance. ${ }^{3,101,123}$ Finally, $\alpha_{2}$-AR blockade may ameliorate sexual dysfunction and counter its disruption by SSRIs. ${ }^{99}$

Based on such considerations, several groups have designed centrally active agents that both antagonize $\alpha_{2}$-ARs and suppress reuptake of 5-HT or NA (or both) in vivo. ${ }^{124,125}$ For example, the spiroimidazoline $\alpha_{2}$-AR antagonist/SNRI, S35966 (FIG. 6), elicits marked increases in frontocortical levels of NA, DA, and 5-HT, compared with SNRIs, is more potent in behavioral models of antidepressant activity, and it more rapidly downregulates $5-\mathrm{HT}_{2 \mathrm{~A}}$ receptors in frontal cortex, a cellular marker of therapeutic activity. ${ }^{126}$ Moreover, in distinction to SNRIs, S35966 releases acetylcholine in frontal cortex, shows procognitive properties in a model of social recognition, and fails to perturb sexual function in rats. ${ }^{126}$

Although such findings are promising, the potential influence of $\alpha_{2}$-AR antagonists/SNRIs on cardiovascular parameters remains a concern, given that sympathetic terminals likewise bear inhibitory $\alpha_{2}$-ARs. Clinical experience with mianserin, a drug that blocks $\alpha_{2}$-AR sites and NA reuptake, is reassuring; however, mianserin also exerts other actions (like $\alpha_{1}$-AR blockade) that may compensate for excursions in circulating levels of NA.,32 Drugs such as RS221661 that block $\alpha_{2}$-ARs and preferentially suppress 5 -HT versus NA reuptake may be more acceptable. ${ }^{125}$ In any event, it seems worth pursuing multifunctional $\alpha_{2}$-AR antagonists plus 5-HT/NA reuptake inhibitors (and comparing their actions to drug combinations), because they may prove effective in patients resistant to or slowly responsive to currently used drugs.

\section{HYBRID \\ MONOAMINERGIC/NONMONOAMINERGIC ANTIDEPRESSANTS}

\section{Histamine $\mathrm{H}_{3}$, nicotinic, and $\mathrm{GABA}_{\mathrm{B}}$ receptors as targets: improving cognitive function}

Histamine $\mathrm{H}_{3}$ receptors are an interesting target because they act as inhibitory autoreceptors on histaminergic neurons and exert a negative influence on frontocortical monoaminergic and cholinergic pathways; accordingly, selective $\mathrm{H}_{3}$ antagonists have procognitive and modest antidepressant properties. ${ }^{127-129}$ However, they are unlikely to be useful per se in depression, which suggests association with another clinically validated mechanism. Several structures interacting both with $\mathrm{H}_{3}$ receptors and with 5-HT transporters were recently described, including JNJ-2583867 (FIG. 6), which increases extracellular levels of 5-HT in frontal cortex and is active in preclinical models of depression. ${ }^{130,131}$ Dualacting $\mathrm{H}_{3}$ antagonists/SRIs represent a promising concept for improved control of mood and cognitive impairment in depression, with a low risk of obesity in view of the inhibitory influence of $\mathrm{H}_{3}$ antagonists on appetite. ${ }^{132}$ Nonetheless, one possible disadvantage is a possible interference with sleep, due to their wake-inducing actions (Table 4).

Stress-responsive cholinergic neurons also broadly influence mood and cognition., ${ }^{3,133}$ Although muscarinic receptors should not be ignored, nicotinic sites are of particular interest, given that several classes of antidepressant, including fluoxetine (SSRI), reboxetine (NARI), and bupropion (DARI) and its active 4-OH metabolite, radafaxine, interact with various nicotinic receptor subunits. ${ }^{3}$ It seems not unreasonable to imagine that optimized dual- and triple-acting nicotinic/monoaminergic antidepressants could be devised. The exact nicotinic receptor subunits to target and the optimal degree of drug efficacy is less obvious, because there is evidence that both partial agonists and/or antagonists at various subtypes of nicotinic receptor can improve mood. ${ }^{3,133-136}$ Currently, the best evidence is that reducing activity of $\alpha_{4} \beta_{2}$ and, possibly, $\alpha_{7}$ sites is related to antidepressant properties. ${ }^{134,136}$ and the preferential $\alpha_{4} \beta_{2}$ antagonist mecamylamine enhances antidepressant actions of SSRIs in humans. ${ }^{137}$ On the other hand, antidepressants with partial agonist actions at $\alpha_{7}$-subunits may improve cognitive function. A further approach to improving cognition in depression is represented by RS-1259, which behaves as a mixed acetylcholinesterase inhibitor/SRI (FIG. 6). ${ }^{138-140}$ Although originally intended for Alzhei- 
mer's disease, its potential in geriatric depression justifies examination.

Many other multitarget approaches to improving cognition and mood in depression could also be cited, including drugs behaving as $\mathrm{GABA}_{\mathrm{B}}$ receptor antagonists, which should exhibit procognitive and antidepressant properties. ${ }^{141-143}$ Indeed, GABA $_{B}$ antagonists enhance the influence of SSRIs on serotonergic transmission in the frontal cortex. ${ }^{87,144,145}$

\section{Glutamatergic receptors as targets: ionotropic and metabotropic hypotheses}

Glutamatergic transmission is responsive to stress, and it is perturbed in depressed states. Furthermore, both ionotropic (AMPA, kainate, and NMDA) and metabotropic (mGluR) I, II, and III receptors are implicated in the control of mood, cognition, circadian rhythms, motor behavior, and other functions perturbed in depression. ${ }^{3,40,90,146-149}$ Blockade of hippocampal NMDA sites may help to protect neurons from deleterious consequences of excessive glutamate and glucocorticoid levels under protracted stress, and to abrogate the HPA overdrive seen early in depressed states. ${ }^{150-152}$ NDMA receptor blockade yields antidepressant actions both singly and in association with SSRIs in rodents. Supporting interest in mixed NMDA agents/SRIs, the open channel blocker ketamine exerts rapid antidepressant properties in patients. ${ }^{153-155}$

Although the risk of cognitive impairment and psychosis tempers interest in channel blockers as a therapeutic strategy, ${ }^{34,146,156}$ the anti-Alzheimer agent memantine has only a low risk of psychosis, because of its marked voltage-dependency and rapid kinetics ${ }^{156-158}$; its potential antidepressant actions are under investigation, although clinical data are as yet ambivalent. ${ }^{159-161}$ In fact, memantine interacts with several other sites ${ }^{156}$ (Table 2), supporting the notion that NMDA receptor blockers could serve as a template for generating well-tolerated multitarget antidepressants of accelerated onset of action. Multitarget drugs could also be constructed around structures specifically blocking NR2B NMDA receptor subunits or the colocalized glycine ${ }_{B}$ sites, which should have a reduced risk of psychosis and other adverse effects. ${ }^{146}$

One theory of the antidepressant actions of NMDA antagonists suggests that they indirectly favor transmission at AMPA versus NMDA sites. ${ }^{155}$ Correspondingly, positive allosteric modulators (ampakines) at AMPA receptors exert antidepressant properties, induce neurogenesis, and favor cognitive performance, both singly and in association with SSRIs. ${ }^{148,162-164}$ An additional incentive to search for drugs with dual ampakine/5-HT reuptake-inhibiting properties is that stimulation of AMPA receptors (in the suprachiasmatic nucleus) may recoordinate circadian rhythms in desynchronized patients. ${ }^{3,165}$ Furthermore, AMPA receptors are involved in antide- pressant actions of lithium, which reliably potentiates SSRI efficacy in patients. ${ }^{166}$ Drugs with joint ampakine/ 5-HT reuptake inhibitory properties could be highly effective antidepressant agents, with a favorable effect on cognition and, possibly, on diurnal rhythms of behavior. However, AMPA receptors are widely distributed, play an important role in sensory transmission in the dorsal horn, and-despite promoting neurogenesis - their stimulation is implicated (possibly along with glucocorticoids) in the neurodegenerative influence of chronic stress. ${ }^{148,156,164,167}$ It will be necessary to establish that antidepressants acting at AMPA receptors neither disrupt sensory transmission nor exacerbate deleterious neuronal effects of sustained stress. The chemical feasibility of dual AMPA facilitators/SRIs is supported by observations that the ampakines LY392,098 and LY404,187 have significant affinity for 5-HT transporters (personal observation).

Several subtypes of mGluR receptor influence mood and HPA activity. For example, mGluR5 receptor antagonists show antidepressant and anxiolytic properties in rodents, ${ }^{149}$ and low-efficacy agonists at mGluR2/3 sites accelerate adaptive changes elicited by chronic treatment with imipramine. ${ }^{168}$ Although structure-activity relationships of orthosteric ligands are restricted, allosteric sites offer scope for generation of mixed mGluR/serotoninergic ligands for improved treatment of depression.

\section{Neuropeptidergic receptors as targets: focus on Neurokinin $_{1}\left(\mathrm{NK}_{1}\right)$ receptor antagonists/SRI}

Genetic or pharmacological invalidation of $\mathrm{NK}_{1}$ receptors has been shown to improve resistance to stress, to promote neurogenesis, and to be accompanied by antidepressant and anxiolytic effects in several (but not all) experimental procedures. ${ }^{3,169,170}$ Acquisition of these data paralleled the therapeutic reorientation of selective $\mathrm{NK}_{1}$ receptor antagonists into the psychiatric domain from the management of pain (where high expectations turned to major disillusion). Despite early clinical indications that discrete blockade of $\mathrm{NK}_{1}$ receptors is associated with antidepressant and, possibly, anxiolytic actions, further studies questioned whether selective $\mathrm{NK}_{1}$ receptor inactivation permits robust and consistent relief of depressed states. ${ }^{170-172}$

It would be naïve, however, to jump to the conclusion that $\mathrm{NK}_{1}$ receptors are irrelevant. Rather, they should be exploited in a multitarget framework, as is reflected in current interest in the conjunction of $\mathrm{NK}_{1}$ receptor antagonism with inhibition of 5-HT reuptake. This concept is of particular interest because blockade of $\mathrm{NK}_{1}$ receptors promotes the activity of corticolimbic adrenergic and dopaminergic pathways, complementing the effects of 5-HT reuptake inhibition. ${ }^{173-177}$ Blockade of $\mathrm{NK}_{1}$ receptors also accelerates the long-term facilitatory influence of SSRIs on serotonergic transmission, possibly 
by accelerating desensitization of inhibitory $5-\mathrm{HT}_{1 \mathrm{~A}}$ autoreceptors. ${ }^{175-177}$ These observations suggest that dual agents may be both more effective and rapid-acting than SSRIs and, inasmuch as $\mathrm{NK}_{1}$ antagonists enhance antidepressant actions of SSRIs yet curtail their anxiogenic effects, ${ }^{3,177,178}$ they should be devoid of the symptoms of nervousness that patients may experience at the beginning of SSRI therapy.

Both SSRIs and $\mathrm{NK}_{1}$ antagonists display anti-impulsive properties, and also blunt light-induced advances of circadian rhythms. ${ }^{3,90,169,179-181}$ As regards tolerability, mixed $\mathrm{NK}_{1}$ antagonists/SRIs should exert a less negative influence on sexual function and sleep than SSRIs and, in view of clinically proven antiemetic properties of $\mathrm{NK}_{1}$ antagonists, they may provoke less nausea. ${ }^{3,170-172,182}$ Accordingly, considerable attention is being devoted to drugs blocking both $\mathrm{NK}_{1}$ receptors and 5-HT transporters. Pioneers in this regard were Ryckmans et al. ${ }^{183}$ (structure UCB in FIG. 7), who showed that dual-acting agents are feasible despite the structural disparity between $\mathrm{NK}_{1}$ receptors and 5-HT transporters.

These arguments should be kept in mind when assessing clinical data with other classes of highly selective neuropeptidergic agents. For example, $\mathrm{NK}_{2}$ receptors may participate in the control of mood, and $\mathrm{NK}_{2}$ antagonists were reported to have antidepressant actions, blunt the response to stress, and counter overdrive of the HPA axis..$^{3,184,185}$ Collectively, these data suggest utility in treating major depression. However, therapeutic effects of the selective $\mathrm{NK}_{2}$ receptor blocker saredutant were not compelling, and it was discontinued. Despite the low density of $\mathrm{NK}_{2}$ receptors in the brain (or at least the healthy brain), it seems justified to contemplate $\mathrm{NK}_{2}$ antagonists/SRIs as potential antidepressants.

The selective vasopressin $\left(\mathrm{V}_{1 \mathrm{~b}}\right)$ receptor antagonist, SSR149415, has been abandoned from clinical trials despite a solid experimental basis supporting its use in depression; more robust effects may be achieved when it is coupled to SRI properties. ${ }^{186-188}$ In addition, notwithstanding experimental evidence for a role of galanin and melanin concentrating hormone in the regulation of mood and cognition, galanin receptor ligands and melanin concentrating hormone ${ }_{1}$ receptor antagonists are conspicuously absent from current drug pipelines-although this may be related to difficulties in finding drugs with appropriate safety and pharmacokinetic profiles, not only to the issue of efficacy. ${ }^{189,190}$ Finally, evidence supporting the relevance of central corticotrophin releasing factor $_{1}\left(\mathrm{CRF}_{1}\right)$ receptors in the response to stress, control of the HPA axis, regulation of mood, and induction of anxious and depressed states is overwhelming, but clinical data with selective antagonists are frustratingly sparse, and the most recent report was negative., 3,90,191,192 For these (and other) neuropeptide receptors, association with SRI properties or other mechanisms controlling depressed states should be envisaged.<smiles>Brc1cc(Br)cc(COC[C@@H](c2ccccc2)N2CCNCC2)c1</smiles>

UCB (NK 1 Antag/SRI)<smiles>CN(Cc1cc(F)cc(Cl)c1)C(=O)C1(N2CCNCC2)Cc2ccccc2C1</smiles>

S 41744 (NK 1 Antag/SRI)<smiles>CN1CCC(CN(C)C(=O)c2cc(C#N)cc3ccccc23)(c2ccc(Cl)c(Cl)c2)CC1</smiles>

Astra (NK 1 Antag/SRI)<smiles>CN1CCC(CC(=O)N(C)Cc2cc(Br)cc(Br)c2)(c2ccc(F)cc2)CC1</smiles>

Glaxo

(NK 1 Antag/SRI)<smiles>CN1CCN(C(CN2CCN(CCCCc3cccc4ccccc34)CC2)c2ccc(F)cc2)CC1</smiles>

MCL0042

( $\mathrm{MC}_{4}$ Antag/SRI)

FIG. 7. Chemical structures of drugs that interact with both neuropeptidergic receptors and 5-HT transporters. UCB, Astra Zeneca

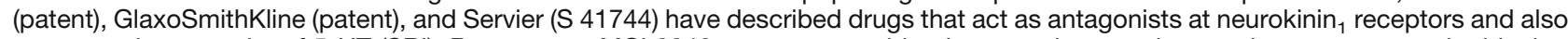

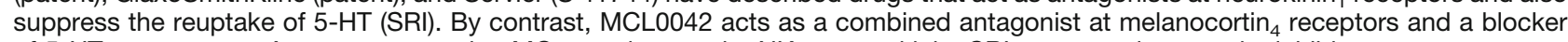
of 5-HT transporters. Antag = antagonist; MC = melanocortin; NK = neurokinin; SRI = serotonin reuptake inhibitor. 
It must be emphasized that the goal of interlinking neuropeptide receptor antagonist and SRI properties is perfectly realistic. For example, in addition to $\mathrm{NK}_{1}$ receptors/SRIs, MCL10004 both suppresses 5-HT reuptake and blocks melanocortin 4 receptors, a dual mechanism that may synergistically improve mood (FIG. 7). ${ }^{193,194}$ Mixed ligands of neuropeptide $\mathrm{Y}_{5}$ receptors and 5-HT transporters have also been described. ${ }^{195}$

The real future of neuromodulatory peptidergic mechanisms may well lie in the multitarget universe, and it is hard to comprehend the persistent obsession with selective agents only. To reiterate, disappointing results with a selective agent do not necessarily imply therapeutic irrelevance but, rather, invite exploitation by means of a multitarget strategy. For all novel targets, it would be wise to concomitantly pursue programs with both selective and multitarget agents. Furthermore, it would appear sensible to explore drug efficacy under a variety of conditions in specific subpopulations of patients, such as those with high stress-sensitivity or HPA axis overdrive, and both in naïve (i.e., never treated) subjects and those resistant to monoaminergic agents.

\section{Innovative neuroendocrine mechanisms: calming HPA axis overdrive and recruiting melatonin receptors}

Together with $\mathrm{V}_{1 \mathrm{~b}}$ receptors, $\mathrm{CRF}_{1}$ receptors comprise key mechanisms for recruiting the endocrine arm of the HPA axis. HPA overdrive under conditions of protracted, intensive, and uncontrollable stress contributes to the pathogenesis of depression and is accompanied by a negative influence on mood, cognition, and neural integrity due to excessive and disproportionate activation of cerebral glucocorticoid (GR) versus mineralocorticoid receptors. 3,167,196,197 Furthermore, HPA overdrive is correlated with poor responsiveness to SSRIs. ${ }^{197}$ Glucocorticoid synthesis inhibitors such as metyrapone promote neurogenesis, display antidepressant actions, and potentiate the actions of SSRIs. 3,198,199 Furthermore, they accelerate antidepressant action of SSRIs in patients. ${ }^{200,201}$

Glucocorticoid antagonists attenuate the reduction of synaptic plasticity by stress, display antidepressant actions in rodents, and exert a positive influence on mood (and cognition) in association with SSRIs in psychotic depression, which is characterized by a pronounced overactivation of the HPA axis. ${ }^{3,167,197,202-204}$ The beneficial effects of GR antagonists and metyrapone involve a sustained induction of mineralocorticoid receptors, as well as serotonergic and dopaminergic mechanisms. ${ }^{3,196,197,199,205-207}$ Agents curtailing HPA overdrive may also abrogate deleterious somatic effects such as obesity, osteoporosis, and coronary artery disease. . $^{3,196}$ Finally, GR antagonists hasten and augment the induc- tion of 5-HT levels elicited by chronic fluoxetine, possibly by accelerating desensitization of $5-\mathrm{HT}_{1 \mathrm{~A}}$ autoreceptors. $^{208}$

These observations support interest in combined inhibitors of 5-HT reuptake plus suppressors of glucocorticoid synthesis or GR receptor antagonists. ${ }^{197,206}$ There are caveats, however: 1) clinical data remain in need of consolidation; 2) only certain patients, such as those with psychotic depression, may be sensitive to treatment, whereas others with atypical depression and seasonal affective disorder show blunted HPA axis activity; 3) the HPA axis is regulated around a set-point, so its activity should not be too strongly compromised; ${ }^{3,167,196,197,206}$ and 4), it would prove challenging to integrate GR blockade and 5-HT reuptake inhibition into a single structure. Thus, despite the interest of calming HPA axis overdrive by dual-acting agents with SRI activity, further work is needed on this concept.

As with GR antagonists, it may prove hard to develop drugs with dual thyroxine activity/SRI properties, despite compelling evidence that $\mathrm{T}_{3}$ supplementation improves the clinical profiles of SSRIs. ${ }^{3,18,21,22}$

Agomelatine, a combined melatonin agonist/5- $\mathrm{HT}_{2 \mathrm{C}}$ antagonist, more concretely illustrates the clinical promise of dual-acting antidepressants integrating neuroendocrine and monoaminergic mechanisms. ${ }^{209-211}$ The importance of $5-\mathrm{HT}_{2 \mathrm{C}}$ receptor blockade in the treatment of depression was outlined above, and melatoninergic agonism offers complementary advantages. Although melatonin (which is released from the pineal gland and acts via $\mathrm{MT}_{1}$ and $\mathrm{MT}_{2}$ receptors in the $\mathrm{SCN}$ ) does not exert marked antidepressant properties per se, it improves sleep and reschedules perturbed circadian rhythms in insomniacs. ${ }^{81,212-214}$ Such actions of agomelatine would be beneficial in depression, inasmuch as patients generally exhibit reduced sleep quality and are often desynchronized. . $^{3,81,82}$

Reflecting melatoninergic agonist and $5-\mathrm{HT}_{2 \mathrm{C}}$ receptor antagonist actions, agomelatine is effective in experimental models of antidepressant and anxiolytic properties. ${ }^{209,210,215,216}$ Agomelatine also counters the suppression by hippocampal neurogenesis by stress, and abrogates HPA axis activation and behavioral indices of depression. ${ }^{217}$ Underscoring its chronobiotic properties, agomelatine recoordinates experimentally perturbed circadian rhythms and sleep in rodents. ${ }^{3,211}$ Correspondingly, agomelatine displays short- and long-term antidepressant properties in patients and, in contrast to SSRIs and SNRIs, sexual behavior is preserved and sleep initiation and quality are improved..$^{209-211,218,219}$ Furthermore, agomelatine is active in severely depressed patients, ${ }^{209-211,218,219}$ and studies underway should more clearly define its potential advantages relative to SSRIs in specific populations of depressed patients (e.g., those with seasonal affective disorder). 


\section{STRATEGIES FOR THE FUTURE? MULTIFUNCTIONAL AGENTS INTERACTING WITH INTRACELLULAR SIGNALS}

Recent years have witnessed something of an infatuation with intracellular proteins as targets for novel antidepressants: such agents may sidestep some of the drawbacks of conventional drugs and (although this is speculative) may counter the destructive effects of stress on neuronal resistance and neuronal plasticity-nebulous terms, though seductive, that are conveniently left undefined. As has become customary, the emphasis has been on highly selective ligands, but this is something of a misnomer, considering the almost universal expression of proteins such as brain-derived neurotropic factor (BDNF) and protein kinase $\mathrm{C}(\mathrm{PKC})$. The idea of a drug target within neurons is not in itself radical, as exemplified by inhibitors of monoamine oxidase. The following examples illustrate the challenges and opportunities faced in exploitation of intracellular targets, and the potential advantages of drugs with dual mechanisms of actions.

Lithium, which is widely used in the control of bipolar disorder, enhances the therapeutic efficacy of antidepressants such as SSRIs. ${ }^{3,9,220,221}$ A reinforcement of monoaminergic transmission, possibly related to a downregulation of $\alpha_{2}-\mathrm{ARs}^{222}$, as well as to AMPA receptor facilitation, ${ }^{166}$ may participate in the mood-improving benefits of lithium supplementation. Nonetheless, improved understanding of the intracellular substrates of lithium action might allow for the design of lithiummimics that avoid its adverse effects (Table 4). ${ }^{223-225}$

Notably, by both direct and upstream (indirect) actions, lithium interferes with the activity (phosphorylation status) of glycogen synthase kinase- $3 \beta$ (GSK- $3 \beta$ ), a highly regulated, constitutively active, and ubiquitous modulator of many proteins which is itself deactivated by phosphorylation. ${ }^{9,223-225}$ Whether GSK-3 exerts a negative influence on mood per se is unclear, but several classes of antidepressant phosphorylate (deactivate) GSK-3 $\beta$, as does electroconvulsive therapy. ${ }^{223-226}$ Furthermore, facilitation of the mood-improving actions of antidepressant by zinc may reflect an inhibitory influence on GSK- $3 \beta,{ }^{227}$ and GSK-3 $\beta$ inhibitors display antidepressant properties in rodent models. ${ }^{228,229}$ Finally, suppression of the proapoptoptic properties of GSK- $3 \beta$ may be involved in the neuroprotective properties of lithium. ${ }^{224}$

A generalized shutdown of GSK-3 $\beta$ would be disquieting in view of its broad physiological role, for example, in energy metabolism. Indeed, selective GSK-3 $\beta$ inhibitors are unlikely to be pursued further in the clinic because of indications of limited tolerability. ${ }^{225}$ Contrariwise, dual inhibition of GSK-3 $\beta$ plus 5-HT reuptake, for example, may permit a less radical reduction in GSK-3 $\beta$ activity and, correspondingly, an enhanced therapeutic margin. In addition, inhibitors may be preferentially active in structures where GSK-3 $\beta$ is putatively upregulated in depression. This is by no means certain, however, and clinical proof is awaited. GSK-3 $\beta$ (and upstream proteins such as PI-3 kinase and Akt) exemplify both the promise and the potential pitfalls of drugs aimed at broadly expressed intracellular targets.

Such promise and pitfalls are likewise illustrated by inhibitors of phosphodiesterase-4 (PDE-4), which prolongs the effects of adenylyl cyclase by protecting cAMP from degradation. ${ }^{230}$ This mechanism is under investigation for diverse disorders, including depression. Indeed, there is experimental and clinical evidence for antidepressant (and procognitive) actions of the PDE-4 inhibitor rolipram, although tolerability is poor: for example, inhibition of PDE-4 in the limbic system and brainstem provokes anxiety and nausea, respectively., 3,230-232 Drugs directed at specific isoforms of PDE-4 should have more regionally specific actions and improved tolerability, but they are unlikely to offer a broadly effective mechanism for improving mood and cognition. PDE-4 inhibition could, thus, be associated with a complementary upstream mechanism that recruits adenylyl cyclase: for example, $\beta$-AR, $5-\mathrm{HT}_{4}$, or $5-\mathrm{HT}_{6}$ receptor agonism. ${ }^{113,117,118,231,232}$ Such a dual-acting drug should mainly inhibit PDE-4 (and hence favor cAMP generation) in structures where $\beta-\mathrm{AR}, 5-\mathrm{HT}_{4}$ or $5-\mathrm{HT}_{6}$ receptors are stimulated. This would increase the therapeutic window and enhance both the efficacy and duration of agonist-mediated actions.

Other intracellular modulators controlling mood could also be cited, such as 1) neuronal nitric oxide, which is recruited by NMDA receptors and interacts with 5 -HT transporters, ${ }^{3,146,233,234}$ or 2) $\sigma_{1}$ sites, which also interact with NMDA receptors and modulate intracellular $\mathrm{Ca}^{2+}$ availability. $3,235-237$

To reiterate, multitarget approaches appear more promising than selective agents for manipulation of intracellular proteins-not least, because they can help vector drug actions to cerebral areas involved in the induction and control of depression. Nonetheless, if antidepressants are designed to act via intracellular mechanisms, then it must be established how to monitor their effects in humans.

\section{GENERAL DISCUSSION AND OPEN QUESTIONS}

\section{Chemical challenges in the design of multitarget agents}

Challenges inherent in the design of selectively nonselective or designed multitarget agents should not be underestimated whether the goal is to 1) eliminate unwanted activities from a template involving multiple components of action, 2) to integrate a novel action into 
a skeleton displaying one of two desirable features, or 3) to start from scratch by introducing two actions into a chemically original fragment. ${ }^{3,10-15,238-241}$

Although spacers are one option for linking two apparently incompatible pharmacophores, they need to be progressively removed in the search for overlapping elements. This is important, because maintaining a small size, modest lipophilicity, and a limited polar surface is compatible with a multitarget profile and critical for appropriate pharmacokinetic properties such as solubility and activity upon oral administration. Structure-activity relationships are hard enough to optimize for single sites, and they are commensurately more difficult when a balance is to be achieved between two or more actions. Nonetheless, as a rule of thumb, theoretical arguments and practical experience indicates that modest affinities at each site for a dual-acting agent are adequate, compared with high potency with a selective agent.

Other potential challenges for racemic structures are the risk that the two components of action differentially segregate among optically pure isomers. Furthermore, there is the potential problem that metabolites do not retain an appropriate multitarget profile. Finally, characterization of drugs with multiple mechanisms of action is more complex, more time-consuming, and more subtle than for selective agents, not least in the attribution of specific desired and undesired actions to individual pharmacological mechanisms. Concepts need to be carefully validated, and there remains the ineluctable question of the ideal ratio of activities - something that is invariably difficult to define, and even harder to systematically realize.

Despite these challenges, based on accumulating experience and the advent of new and powerful tools for analyzing and (tentatively) predicting drug polypharmacology, one may be optimistic that medicinal chemists will continue to progress toward the successful design of multitarget agents. ${ }^{3,10-15,238-246}$

\section{Comparison of multitarget agents to drug associations}

In advocating drugs with dual mechanisms of activity, an obvious question arises of how they compare to drug associations - that is, to mixtures of two or more compounds, either within a single treatment form (usually tablet) or given as a mixture. ${ }^{244,247,248}$ The various advantages of multitarget drugs may be summarized as follows. $^{3}$

First, effects of drug mixtures are not invariably the same as those of drugs with multiple mechanisms of action. Furthermore, although associating drugs might realistically reproduce the effects of drugs with dual mechanisms of action, this is increasingly unlikely for triple-acting drugs or for those with even more mechanisms of action.
Second, to develop drug mixtures, it is desirable to establish optimal drug doses (exposure) both separately and together, an onerous process.

Third, it is likewise necessary to undertake pharmacokinetic, safety, and galenic studies both on drugs alone and on their association, further complicating development.

Fourth, it is hard to predict the exact nature of interactions among drug mixtures, and the problem of interactions with other drug classes is even more challenging than for a single agent.

Fifth, compliance is a major problem in depression and other CNS disorders and is unlikely to be favored by multiplying the number of tablets to be taken.

Sixth, non-evidence-based polypharmacy is worryingly common for psychiatric disorders. It has been strongly challenged and is generally discouraged. Thus, it is difficult to promote the use of drug mixtures.

Seventh, for drugs to be combined they must present similar pharmacokinetic profiles. There is little sense in associating drugs with radically different half-lives.

Eighth, drug combinations necessitate considerable experience with the individual agents separately, and cannot be easily envisioned for mechanisms where clinical feedback is minimal or lacking. In certain cases, the relevant selective agent may simply not exist.

Ninth, multitarget drugs offer greater flexibility and opportunities from the point of view of intellectual property in terms of novel chemical structures and multiple mechanisms of action. Moreover, patents on novel drugs are far more robust than use patents and association patents, especially when the latter taken on agents previously patented by other institutions.

Finally, clinical testing and use of drugs from two different sources (e.g., two different pharmaceutic firms) is complicated, even if either or both are available as generics.

Nonetheless, the core point remains: the likely therapeutic benefits of multiple mechanisms of antidepressant action. In certain cases, drug combinations may well be warranted. For example, there is a limit to how many pharmacophores can realistically be introduced into a single structure, and chemical constraints complicate the design of certain classes of putative multitarget agent, such as mixed GR antagonists/SRIs. Furthermore, however challenging, drug combinations in theory permit the clinical definition of optimal ratios of activity for two complementary mechanisms, whereas the ratio is invariant for a dual-acting agent. It may also be possible to adapt combinations of specific drugs to the particular genetic and clinical profiles of individual patients, although this could prove problematic and should not be performed on an ad hoc basis. Economic considerations may also come to the fore, should the use of generic 
associations prove substantially cheaper than novel multitarget agents of equivalent efficacy.

Thus, from a pathophysiological, conceptual, and clinical point of view, concomitant treatment with two wellcharacterized mechanisms should not be neglected, especially where they can be integrated into a single treatment (e.g., tablet). ${ }^{248}$ Specific examples of drug combinations include a paroxetine (SSRI) plus vestipitant $\left(\mathrm{NK}_{1}\right.$ antagonist) formulation, and fluoxetine (SSRI) plus olanzapine (atypical antipsychotic). ${ }^{20,177}$

\section{Network concepts of CNS function and dysfunction: the need for early intervention}

Mood, cognition, and other functions disrupted in depression are emergent properties of overarching cerebral circuits, rather than of individual proteins, receptors, or neurons. The brain-its organization, operation, perturbation and treatment-is best understood in terms of functional modules and networks at a hierarchy of scales: from receptors, G-proteins, and their postsynaptic partners to neuronal circuits to regions such as the frontal cortex..$^{3,249-256}$ Mimicking other nonrandom networks, such as ecosystems, and reflecting the redundancy and differential responsiveness of numerous mechanisms controlling mood, ${ }^{3,257-259}$ the brain is rather resistant to stress. Nonetheless, when stress (especially if multiple, intense, and/or protracted) disrupts brain networks, consequences can be serious (major depression being the example under consideration). ${ }^{3,253,260-263}$

As already stressed, drugs acting at key modes (hubs) such as $5-\mathrm{HT}_{2 \mathrm{C}}$ receptors can be useful. However, mirroring the multitarget operation of the brain, drugs acting at several hubs or at multiple weak links may more effectively restore dysfunctional networks. $3,10-15,57,240,241$ Furthermore, because phase-shifts to pathological states cannot easily be reversed (hysteresis), it is important to act with immediacy and even preventatively ${ }^{3,4,16}$ (FIG. 8): hence the key importance of biomarkers for incipient depressed states.

These principles of network-based, multitarget, and (by preference) early intervention apply to other complex CNS disorders such as fibromyalgia, ${ }^{264}$ bipolar disorder, ${ }^{265}$ Parkinson's disease, ${ }^{266,267}$ and Alzheimer's dis-

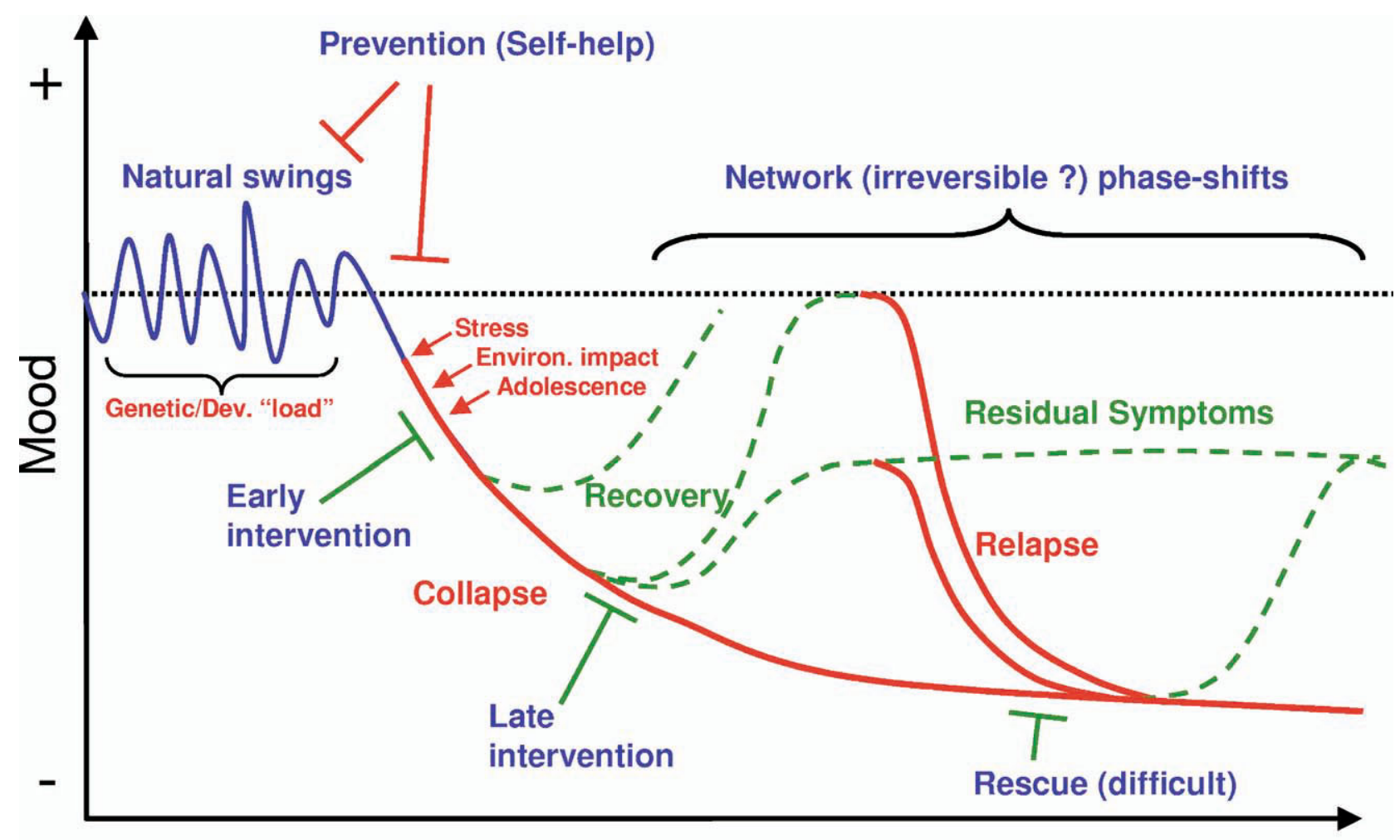

\section{Time (months/years)}

FIG. 8. The life-cycle of major depression and its treatment. Mood and its perturbation is under the influence of many, interacting genetic, epigenetic and developmental factors ("load"). Preventive strategies (often "self-help") help maintain equilibrium during natural swings in mood and in the face of threats to homeostasis. Such environmental challenges encapsulated under the term stress can be especially dangerous during adolescence and young adulthood. Because networks controlling mood may phase-shift into a new configuration that is hard to reverse (hysteresis), early treatment of incipient depressed states is crucial, whether by pharmacotherapy, other approaches, or both. Such treatments are also important as long-term strategies for countering residual symptoms and reducing the risk of relapse. Once well-established, and after multiple relapses, depressed states are hard to treat. These arguments apply not to only to dual- and triple-acting agents but to all classes of therapy. 
ease, ${ }^{268,269}$ as well as somatic disorders such as cancer, AIDS, and malaria. ${ }^{270-274}$

\section{A valedictory caveat}

Antidepressants with multitarget mechanisms are not synonymous with superior or better-tolerated antidepressants, as is exemplified by the off-target actions of tricyclic agents. Moreover, the benefits of certain dualacting drugs, relative to single-target alternatives, are not spectacular. SNRIs show greater efficacy than SSRIs overall, and have a broader therapeutic range (e.g., against neuropathic pain), but their advantages are not dramatic and may be offset by other factors, such as an enhanced risk of hypertension. . $35,37,38,275$ In fact, rather inconveniently, the SSRI escitalopram appears to be equivalent in efficacy to SNRIs—although perhaps reflecting its distinctive multisite interaction with 5-HT transporters. ${ }^{276,277}$ By analogy, mirtazapine (which has antagonist properties at $\alpha_{2}$-ARs, $5-\mathrm{HT}_{2 \mathrm{C}}$, and $5-\mathrm{HT}_{3}$ receptors) is more effective than selective $\alpha_{2}$-AR or $5-\mathrm{HT}_{3}$ antagonists, but it remains unknown how it compares with a selective $5-\mathrm{HT}_{2 \mathrm{C}}$ antagonist in the clinic. ${ }^{3,85,97} \mathrm{In}$ addition, the benefits of mirtazapine are compromised by potent histamine $\mathrm{H}_{1}$ antagonism.

There is much room for improvement on currently available multitarget drugs. Careful validation of innovative concepts and thorough drug characterization will be critical for improving efficacy and tolerability in the next wave of dual- and triple-acting antidepressants.

\section{CONCLUSION}

In light of the heterogeneity and multifactorial origins of depression, it is debatable whether its diversity of core and comorbid symptoms can be rapidly and efficaciously relieved, in a majority of patients and with minimal undesirable adverse effects, by drugs acting at a single site-and no multitarget mechanism is likely to fulfill this (illusory?) goal, either. Nonetheless, network-impaired dual, triple-acting and higher-order multitarget drugs appear to offer the best hope for the improved control of affective disorders by pharmacotherapy.

In this light, the bimodal and trimodal concepts discussed in this review address both common and contrasting features of depressed states. These strategies should then be considered as complementary and, in the absence of clinical data, it would be premature to come to any definitive conclusions on their relative merits. Only imaginative and rigorous clinical trials can provide compelling answers to such questions.

Finally, the significance of complementary (and validated) nonpharmacological treatments for prevention and treatment of depression must not be neglected. As discussed elsewhere, ${ }^{34}$ multitarget agents will likely find their optimal use within the framework of a broader program of drug-based and non-drug-based strategies for controlling and preventing depressed states.

Acknowledgments: Marianne Soubeyran is thanked for secretarial assistance, Jean-Michel Rivet for graphics, and Gilbert Lavielle for assistance with chemical structures.

\section{REFERENCES}

1. Hasler G, Drevets WC, Manji HK, Charney DS. Discovering endophenotypes for major depression. Neuropsychopharmacology 2004;29:1765-1781.

2. Morilak DA, Frazer A. Antidepressants and brain monoaminergic systems: a dimensional approach to understanding their behavioural effects in depression and anxiety disorders. Int $\mathbf{J}$ Neuropsychopharmacol 2007;7:193-218.

3. Millan MJ. Multi-target strategies for the improved treatment of depressive states: conceptual foundations and neuronal substrates, drug discovery and therapeutic application. Pharmacol Ther 2006;110,135-370.

4. Millan MJ. The discovery and development of pharmacotherapy for psychiatric disorders: a critical survey of animal and translational models, and perspectives for their improvement. In: McArthur R, Borsini F, Translational models for CNS drug discovery. Vol 1: Psychiatric disorders. New York: Academic Press, 2008;32-89.

5. Hollon SD, Stewart MO, Strunk D. Enduring effects for cognitive behavior therapy in the treatment of depression and anxiety. Annu Rev Psychol 2006;57:285-315.

6. Eitan R, Lerer B. Nonpharmacological, somatic treatments of depression: electroconvulsive therapy and novel brain stimulation modalities. Dialogues Clin Neurosci 2006;8:241-258.

7. Baghai TC, Grunze H, Sartorius N. Antidepressant medications and other treatments of depressive disorders: a CINP task force report based on a review of evidence. Int J Neuropsychopharmacol 2007;10 Suppl 1:S1-S207.

8. O'Reardon JP, Solvason HB, Janicak PG, et al. Efficacy and safety of transcranial magnetic stimulation in the acute treatment of major depression: a multisite randomized controlled trial. Biol Psychiatry 2007;62:1208-1216.

9. Berton O, Nestler EJ. New approaches to antidepressant drug discovery: beyond monoamines. Nat Rev Neurosci 2006;7:137151.

10. Castrén E. Is mood chemistry? Nat Rev Neurosci 2005;6:241246.

11. Csermely P. Strong links are important, but weak links stabilize them. Trends Biochem Sci 2004;29:331-334.

12. Csermely P, Agoston V, Pongor S. The efficiency of multi-target drugs: the network approach might help drug design. Trends Pharmacol Sci 2005;26:180-182.

13. Morphy R, Rankovic Z. The physicochemical challenges of designing multiple ligands. J Med Chem 2006;49:4961-4970.

14. Morphy R, Rankovic Z. Fragments, network biology and designing multiple ligands. Drug Discov Today 2007;12:156-160.

15. Wong EHF, Nikam SS, Shahid M. Multi- and single-target agents for major psychiatric diseases: therapeutic opportunities and challenges. Curr Opin Investig Drugs 2008;9:28-36.

16. Huang S. Rational drug discovery: what can we learn from regulatory networks? Drug Discov Today 2002;7(20 Suppl):S163S169.

17. Holsboer F. How can we realize the promise of personalized antidepressant medicines? Nat Rev Neurosci 2008;9:638-646.

18. Cooper-Kazaz, Lerer B. Efficacy and safety of triiodothyronine supplementation in patients with major depressive disorder treated with specific serotonin reuptake inhibitors. Int J Neuropsychopharmacol 2008;11:685-699.

19. McIntyre M, Moral MA. Augmentation in treatment-resistant depression. Drugs Fut 2006;31:1069-1081.

20. Rasmussen K. Creating more effective antidepressants: clues from the clinic. Drug Discov Today 2006;11:623-631. 
21. Rojo JE, Ros S, Agüera L, de la Gándara J, de Pedro JM. Combined antidepressants: clinical experience. Acta Psychiatr Scand Suppl 2005;(428):25-31.

22. Ros S, Agüera L, de la Gándara J, Rojo JE, de Pedro JM. Potentiation strategies for treatment-resistant depression. Acta Psychiatr Scand Suppl 2005;(428):14-24,36.

23. Benedetti F, Barbini B, Colombo C, Smeraldi E. Chronotherapeutics in a psychiatric ward. Sleep Med Rev 2007;11:509-522.

24. Barrett J, Della-Maggiore V, Chouinard PA, Paus T. Mechanisms of action underlying the effect of repetitive transcranial magnetic stimulation on mood: behavioral and brain imaging studies. Neuropsychopharmacology 2004;29:1172-1189.

25. Kraus T, Hösl K, Kiess O, et al. BOLD fMRI deactivation of limbic and temporal brain structures and mood enhancing effect of transcutaneous vagus nerve stimulation. J Neural Transm 2007;114:1485-1493.

26. Johansen-Berg H, Gutman DA, Behrens TEJ, et al. Anatomical connectivity of the subgenual cingulate region targeted with deep brain stimulation for treatment-resistant depression. Cereb Cortex 2007;18:1374-1383.

27. Roffman JL, Marci CD, Glick DM, Dougherty DD, Rauch SL. Neuroimaging and the functional neuroanatomy of psychotherapy. Psychol Med 2005;35:1385-1398.

28. De Maat SM, Dekker J, Schoevers RA, de Jonghe F. Relative efficacy of psychotherapy and combined therapy in treatment of depression: a meta-analysis. Eur Psychiatry 2007;22:1-8.

29. Kennedy SH, Konarski JZ, Segal ZV, et al. Differences in brain glucose metabolism between responders to $\mathrm{CBT}$ and venlafaxine in a 16-week randomized controlled trial. Am J Psychiatry 2007; 164:778-788.

30. Luty SE, Carter JD, McKenzie JM, et al. Randomised controlled trial of interpersonal psychotherapy and cognitive-behavioral therapy for depression. Br J Psychiatry 2007;190:496-502.

31. Anderson IM. Selective serotonin reuptake inhibitors versus tricyclic antidepressants: a meta-analysis of efficacy and tolerability. J Affective Dis 2000;58:19-36.

32. Pacher P, Kecskemeti V. Cardiovascular side effects of new antidepressants and antipsychotics: new drugs, old concerns? Curr Pharm Design 2004;10:2463-2475.

33. Tegeder I, Geisslinger G. Cardiovascular risk with cyclooxygenase inhibitors: general problem with substance specific differences? Naunyn Schmiedebergs Arch Pharmacol 2006;373:1-17.

34. Millan MJ, Brocco M. Cognitive impairment in schizophrenia: developmental and genetic models, and pro-cognitive profile of the optimised $\mathrm{D}_{3}>\mathrm{D}_{2}$ antagonist, S33138. Therapie 2008; 63:187-229.

35. Barbui C, Hotopf M. Amitriptyline v. the rest: still the leading antidepressant after 40 years of randomised controlled trials. Br J Psychiatry 2001;178:129-144.

36. Malhi GS, Parker GB, Greenwood J. Structural and functional models of depression: from sub-types to substrates. Acta Psychiatr Scand 2005;111:94-105.

37. Papakostas GI, Thase ME, Fava M, Nelson JC, Shelton RC. Are antidepressant drugs that combine serotonergic and noradrenergic mechanisms of action more effective than the selective serotonin reuptake inhibitors in treating depressive disorder? A meta-analysis of studies of newer agents. Biol Psychiatry 2007;62:12171227.

38. Montgomery SA, Baldwin DS, Blier P, et al. Which antidepressants have demonstrated superior efficacy? A review of the evidence. Int Clin Psychopharmacol 2007;22:323-329.

39. Devoto P, Flore G, Pira L, Longu G, Gessa GL. Mirtazapineinduced co-release of dopamine and noradrenaline from noradrenergic neurons in the medial prefrontal and occipital cortex. Eur J Pharmacol 2004;487:105-111.

40. Millan MJ, Lejeune F, Gobert A. Reciprocal autoreceptor and heteroreceptor control of serotonergic, dopaminergic and noradrenergic transmission in the frontal cortex: relevance to the actions of antidepressant agents. J Psychopharmacol 2000;14: $114-138$.

41. Nestler EJ, Carlzon WA. The mesolimbic dopamine reward circuit in depression. Biol Psychiatry 2006;59:1151-1159.
42. Hull EM, Muschamp JW, Sato S. Dopamine and serotonin: influences on male sexual behavior. Physiol Behav 2004;83:291307.

43. El-Ghundi M, O'Dowd BF, George SR. Insights into the role of dopamine receptor systems in learning and memory. Rev Neurosci 2007;18:37-66.

44. Trivedi MH, Fava M, Wisniewski SR, et al. Medication augmentation after the failure of SSRIs for depression. N Engl J Med 2006;354:1243-1252.

45. Prica C, Hascoet M, Bourin M. Is co-administration of bupropion with SSRIs and SNRIs in forced swim test in mice predictive of efficacy in resistant depression? Behav Brain Res 2008;194: 92-99.

46. Axford L, Boot JR, Hotten TM, et al. Bicyclo[2.2.1.]heptanes as novel triple re-uptake inhibitors for the treatment of depression. Bioorg Med Chem Lett 2003;13:3277-3280.

47. Shaw AM, Boules M, Zhang Y, et al. Antidepressant-like effects of novel triple reuptake inhibitors, PRC025 and PRC050. Eur J Pharmacol 2007;555:30-36.

48. Skolnick P, Basile AS. Triple reuptake inhibitors as antidepressants. Drug Discov Today Ther Strateg 2006;3:489-494.

49. Skolnick P, Krieter P, Tizzano J, et al. Preclinical and clinical pharmacology of DOV 216,303, a "triple" reuptake inhibitor. CNS Drug Rev 2006;12:123-134.

50. Zhang S, Fernandez F, Hazeldine S, et al. Further structural exploration of trisubstituted asymmetric pyran derivatives $(2 S, 4 R, 5 R)$-2-benzhydryl-5-benzylamino-tetrahydropyran-4-ol and their corresponding disubstituted $(3 S, 6 S)$ pyran derivatives: a proposed pharmacophore model for high-affinity interaction with the dopamine, serotonin, and norepinephrine transporters. J Med Chem 2006;49:4239-4247.

51. Aluisio L, Lord B, Barbier AJ, et al. In-vitro and in-vivo characterization of JNJ-7925476, a novel triple monoamine uptake inhibitor. Eur J Pharmacol 2008;587:141-146.

52. Samaha AN, Robinson TE. Why does the rapid delivery of drugs to the brain promote addiction? Trends Pharmacol Sci 2005;26: $82-87$.

53. Volkow ND, Wang GJ, Fowler JS, et al. The slow and longlasting blockade of dopamine transporters in human brain induced by the new antidepressant drug radafaxine predict poor reinforcing effects. Biol Psychiatry 2005;57:640-646.

54. Hauser RA, Salin L, Juhel N, Konyago VL. Randomized trial of the triple monoamine reuptake inhibitor NS 2330 (tesofensine) in early Parkinson's disease. Mov Disord 2007;22:359-365.

55. Artigas F, Adell A, Celada P. Pindolol augmentation of antidepressant response. Curr Drug Targets 2006;7:139-147.

56. Gobert A, Millan MJ. Modulation of dialysate levels of dopamine, noradrenaline, and serotonin (5-HT) in the frontal cortex of freely-moving rats by $(-)$-pindolol alone and in association with 5-HT reuptake inhibitors: comparative roles of $\beta$-adrenergic, $5-\mathrm{HT}_{1 \mathrm{~A}}$, and 5-HT ${ }_{1 \mathrm{~B}}$ receptors. Neuropsychopharmacology 1999; 21:268-284.

57. Bymaster FP, McNamara RK, Tran PV. New approaches to developing antidepressants by enhancing monoaminergic neurotransmission. Expert Opin Investig Drugs 2003;12:531-543.

58. Celada P, Puig MV, Amargós-Bosch M, Adell A, Artigas F. The therapeutic role of $5-\mathrm{HT}_{1 \mathrm{~A}}$ and $5-\mathrm{HT}_{2 \mathrm{~A}}$ receptors in depression. J Psychiatry Neurosci 2004;29:252-265.

59. Weikop P, Kehr J, Scheel-Krüger J. Reciprocal effects of combined administration of serotonin, noradrenaline and dopamine reuptake inhibitors on serotonin and dopamine in the rat prefrontal cortex: the role of 5- $\mathrm{HT}_{1 \mathrm{~A}}$ receptors. J Psychopharmacol 2007; 21:795-804.

60. Dawson LA, Bromidge SM. 5-HT 1 receptor augmentation strategies as enhanced efficacy: therapeutics for psychiatric disorders Curr Top Med Chem 2008;8:1008-1023.

61. Rex A, Voigt JP, Wicke KM, Fink H. In vivo/ex vivo and behavioural study on effects of $5-\mathrm{HT}_{1 \mathrm{~B} / 1 \mathrm{D}}$ and $5-\mathrm{HT}_{1 \mathrm{~A}}$ antagonists in guinea pigs. Pharmacol Biochem Behav 2008;88:196-204.

62. Hatzenbuhler NT, Evrard DA, Harrison BL, et al. Synthesis and biological evaluation of novel compounds within a class of 3-aminochroman derivatives with $5-\mathrm{HT}_{1 \mathrm{~A}}$ receptor and serotonin transporter affinity. J Med Chem 2006;49:4785-4789. 
63. Butler SG, Meegan J. Recent developments in the design of anti-depressive therapies: targeting the serotonin transporter. Curr Med Chem 2008;15:1737-1761.

64. Gobert A, Rivet JM, Cistarelli L, Melon C, Millan MJ. Buspirone modulates basal and fluoxetine-stimulated dialysate levels of dopamine, noradrenaline and serotonin in the frontal cortex of freely moving rats: activation of serotonin ${ }_{1 \mathrm{~A}}$ receptors and blockade of $\alpha_{2}$-adrenergic receptors underlie its actions. Neuroscience 1999; 93:1251-1262.

65. De Paulis T. Drug evaluation: vilazodone-a combined SSRI and $5-\mathrm{HT}_{1 \mathrm{~A}}$ partial agonist for the treatment of depression. Idrugs 2007;10:193-201.

66. Jordan S, Chen R, Koprivica V, et al. In vitro profile of the antidepressant candidate OPC-14523 at rat and human 5-HT 1 A receptors. Eur J Pharmacol 2005;517:165-173.

67. Tottori K, Miwa T, Uwahodo Y, et al. Antidepressant-like responses to the combined sigma and $5-\mathrm{HT}_{1 \mathrm{~A}}$ receptor agonist OPC-14523. Neuropharmacology 2001;41:976-988.

68. Millan MJ, Marin P, Bockaert J, Mannoury la Cour C. Signaling at G-protein-coupled serotonin receptors: recent advances and future research directions. Trends Pharmacol Sci 2008;29: $454-64$.

69. Heightman TD, Gaster LM, Pardoe SL, et al. 8-Piperazinyl-2,3dihydropyrrolo[3,2-g]isoquinolines: potent, selective, orally bioavailable $5-\mathrm{HT}_{1}$ receptor ligands. Bioorg Med Chem Lett 2005; $15: 4370-4374$.

70. Ward SE, Eddershaw PJ, Scott CM, et al. Discovery of potent, orally bioavailable, selective $5-\mathrm{HT}_{1 \mathrm{~A} / \mathrm{B} / \mathrm{D}}$ receptor antagonists. J Med Chem 2008;51:2887-2890.

71. Hughes ZA, Starr KR, Scott CM, et al. Simultaneous blockade of $5-\mathrm{HT}_{1 \mathrm{~A} / \mathrm{B}}$ receptors and 5-HT transporters results in acute increases in extracellular 5-HT in both rats and guinea pigs: in vivo characterization of the novel 5- $\mathrm{HT}_{1 \mathrm{~A} / \mathrm{B}}$ receptor antagonist/5-HT transport inhibitor SB-649915-B. Psychopharmacology (Berl) 2007;192:121-133.

72. Starr KR, Price GW, Watson JM, et al. SB-649915-B, a novel $5-\mathrm{HT}_{1 \mathrm{~A} / \mathrm{B}}$ autoreceptor antagonist and serotonin reuptake inhibitor, is anxiolytic and displays fast onset activity in the rat social interaction test. Neuropsychopharmacology 2007;32:2163-2172.

73. Watson JM, Dawson LA. Characterization of the potent $5-\mathrm{HT}_{1 \mathrm{~A} / \mathrm{B}}$ receptor antagonist and serotonin reuptake inhibitor SB-649915: preclinical evidence for hastened onset of antidepressant/anxiolytic efficacy. CNS Drug Rev 2007;13:206-223.

74. Millan MJ, Gobert A, Roux S, et al. The serotonin ${ }_{1 \mathrm{~A}}$ receptor partial agonist S15535 [4-(benzodioxan-5-yl)1-(indan-2yl)piperazine] enhances cholinergic transmission and cognitive function in rodents: a combined neurochemical and behavioral analysis. J Pharmacol Exp Ther 2004;311:190-203.

75. King MV, Marsden CA, Fone KCF. A role of the 5-HT $1 \mathrm{~A}, 5-\mathrm{HT}_{4}$ and $5-\mathrm{HT}_{6}$ receptors in learning and memory. Trends Pharmacol Sci 2008;29:482-492.

76. Wesołowska A, Nikiforuk A, Stachowicz K, Tatarczyńska E. Effect of the selective 5- $\mathrm{HT}_{7}$ receptor antagonist SB269,970 in models of anxiety and depression. Neuropharmacology 2006;51:578-586.

77. Wesołowska A, Tatarczyńska E, Nikiforuk A, Chojnacka-Wǒjcik E. Enhancement of the anti-immobility action of antidepressant by a selective $5-\mathrm{HT}_{7}$ receptor antagonist in the forced swimming test in mice. Eur J Pharmacol 2007;555:43-47.

78. Bonaventure P, Kelly L, Aluisio L, et al. Selective blockade of 5-hydroxytryptamine $(5-\mathrm{HT})_{7}$ receptors enhances 5-HT transmission, antidepressant-like behavior, and rapid eye movement sleep suppression induced by citalopram in rodents. J Pharmacol Exp Ther 2007;321:690-698.

79. Mnie-Filali O, Lambas-Senas L, Zimmer L, Haddjeri N. 5-HT receptor antagonists as a new class of antidepressants. Drug News Perspect 2007;20:613-618.

80. Thomas DR, Melotto S, Massagrand M, et al. SB656,104-A, a novel selective $5-\mathrm{HT}_{7}$ receptor antagonist, modulates REM sleep in rats. Br J Pharmacol 2003;139:705-714.

81. McClung CA. Circadian genes, rhythms and the biology of mood disorders. Pharmacol Ther 2007;114:222-232.
82. Bunney JN, Potkin SG. Circadian abnormalities, molecular clock genes and chronobiological treatments in depression. Br Med Bull 2008;86:23-32.

83. Thomas DR. 5-HT 5 receptors as a therapeutic target. Pharmacol Ther 2006;111:707-714.

84. Thomas DR, Soffin EM, Roberts C, et al. SB-699551-A (3-cyclopentyl-N-[2-(dimethylamino)ethyl]-N-[(4'-\{[(2-phenylethyl) amino]methyl \}-4-biphenylyl)methyl]propanamide dihydrochloride), a novel 5-ht5A receptor-selective antagonist, enhances 5-HT neuronal function: Evidence for an autoreceptor role for the 5-ht5A receptor in guinea pig brain. Neuropharmacology 2006;51:566-577.

85. Millan MJ. Serotonin $5-\mathrm{HT}_{2 \mathrm{C}}$ receptors as a target for the treatment of depressive and anxious states: focus on novel therapeutic strategies. Therapie 2005;60:441-460.

86. Dekeyne A, Mannoury la Cour C, Gobert A, et al. S32006, a novel $5-\mathrm{HT}_{2 \mathrm{C}}$ receptor antagonist displaying broad-based antidepressant and anxiolytic properties in rodent models. Psychopharmacology (Berl) 2008;199:549-568.

87. Cremers TI, Rea K, Bosker FJ, et al. Augmentation of SSRI effects on serotonin by $5-\mathrm{HT}_{2 \mathrm{C}}$ antagonists: mechanistic studies. Neuropsychopharmacology 2007;32:1550-1557.

88. Heisler LK, Pronchuk N, Nonogaki K, et al. Serotonin activates the hypothalamic-pituitary-adrenal axis via $5-\mathrm{HT}_{2 \mathrm{C}}$ receptor stimulation. J Neurosci 2007;27:6956-6964.

89. Heisler LK, Zhou L, Bajwa P, Hsu J, Tecott LH. Serotonin 5- $\mathrm{HT}_{2 \mathrm{C}}$ receptors regulate anxiety-like behavior. Genes Brain Behav 2007;6:491-496.

90. Millan MJ. The neurobiology and control of anxious states. Prog Neurobiol 2003;70:83-244.

91. Kantor S, Jakus R, Molnar E, et al. Despite similar anxiolytic potential, the 5-hydroxytryptamine $2 \mathrm{C}$ receptor antagonist SB-242084 [6-chloro-5-methyl-1-[2-(2-methylpyrid-3-yloxy)-pyrid5 -yl carbamoyl] indoline] and chlordiazepoxide produced differential effects on electroencephalogram power spectra. J Pharmacol Exp Ther 2005;315:921-930.

92. Dekeyne A, Denorme B, Monneyron S, Millan MJ. Citalopram reduces social interaction in rats by activation of serotonin (5HT) $)_{2 C}$ receptors. Neuropharmacology 2000;39:1114-1117.

93. Salchner P, Singewald N. 5-HT receptor subtypes involved in anxiogenic-like action and Fos response of acute fluoxetine treatment in rats. Psychopharmacology (Berl) 2006;185:282-288.

94. Dekeyne A, Mannoury la Cour C, Chanrion B, et al. S32212, a "dual" antagonist at $\alpha 2$-adrenoceptors (ARs) and 5- $\mathrm{HT}_{2 \mathrm{C}}$ receptors: binding profile and functional action at G-protein-coupled receptors. Am Soc Neurosci Abstr 2006;32:828.2 (abstract).

95. Gobert A, Dekeyne A, Brocco M, et al. S32212, a "dual" antagonist at $\alpha 2$-adrenoceptors (ARs) and 5- $\mathrm{HT}_{2 \mathrm{C}}$ receptors: actions in behavioral and neurochemical models of potential antidepressant and pro-cognitive activity. Am Soc Neurosci Abstr 2006;32: 828.3 (abstract).

96. Rauggi R, Cassanelli A, Raone A, Tagliamonte A, Gambarana C. Study of mirtazapine antidepressant effects in rats. Int J Neuropsychopharmacol 2005;8:369-379.

97. Szegedi A, Schwertfeger N. Mirtazapine: a review of its clinical efficacy and tolerability. Expert Opin Pharmacother 2005;6:631641.

98. Millan MJ, Gobert A, Rivet JM, et al. Mirtazapine enhances frontocortical dopaminergic and adrenergic, but not serotonergic, transmission by blockade of $\alpha 2$-adrenergic and serotonin ${ }_{2 C}$ receptors: a comparison with citalopram. Eur J Neurosci 2000;12: 1079-1095.

99. Tam SW, Worcel M, Wyllie M. Yohimbine: a clinical review. Pharmacol Ther 2001;91:215-243.

100. Invernizzi RW, Garattini S. Role of presynaptic $\alpha_{2}$-adrenoceptors in antidepressant action: recent findings from microdialysis studies. Prog Neuropsychopharmacol Biol Psychiatry 2004;28:819827.

101. Lapiz MD, Morilak DA. Noradrenergic modulation of cognitive function in rat medial prefrontal cortex as measured by attentional set shifting capability. Neuroscience 2006;137:1039-1049.

102. Hemrick-Luecke SK, Evans DC. Comparison of the potency of MDL100,907 and SB242,084 in blocking 5- $\mathrm{HT}_{2}$ agonist-induced 
increases corticosterone: evidence for 5- $\mathrm{HT}_{2 \mathrm{~A}}$ mediation of HPA axis. Neuropharmacology 2002;42:162-169.

103. Geyer MA, Vollenweider FX. Serotonin research: contributions to understanding psychoses. Trends Pharmacol Sci 2008;29:445453.

104. Fujiwara-Sawada M, Imanishi T, Yoshida A, Baba J. Possible involvement of peripheral 5- $\mathrm{HT}_{3}$ receptors in fluvoxamine-induced emesis in Suncus murinus. J Pharm Pharmacol 2003;55: 271-274.

105. Costall B, Naylor RJ. 5- $\mathrm{HT}_{3}$ receptors. Curr Drug Targets 2004; 3:27-37.

106. Harmer CJ, Reid CB, Ray MK, Goodwin GM, Cowen PJ. 5-HT antagonism abolishes the emotion potentiated startle effect in humans. Psychopharmacology (Berl) 2006;186:18-24.

107. Ramamoorthy R, Radhakrishnan M, Borah M. Antidepressantlike effects of 5- $\mathrm{HT}_{3}$ antagonist, ondansetron: an investigation in behaviour-based rodent models. Behav Pharmacol 2008;19: 29-40.

108. Moore NA, Bang-Andersen B, Brennum LT, et al. Lu AA21004: a novel potential treatment for mood disorders. Eur Neuropsychopharmacol 2008;18 Suppl 4:S321 (abstract).

109. Millan MJ, Di Cara B, Dekeyne A, et al. Selective blockade of dopamine $\mathrm{D}_{3}$ versus $\mathrm{D}_{2}$ receptors enhances frontocortical cholinergic transmission and social memory in rats: a parallel neurochemical and behavioural analysis. J Neurochem 2007;100:10471061.

110. Loiseau F, Millan MJ. Blockade of dopamine $D_{3}$ receptors in frontal cortex, but not in sub-cortical structures, enhances social recognition in rats: similar actions of $D_{1}$ receptor agonists, but not of $\mathrm{D}_{2}$ antagonists. Eur Neuropsychopharmacol 2008 Sept 14 [Epub ahead of print].

111. Norman TR, Burrows GD. Emerging treatments for major depression. Expert Rev Neurother 2007;7:203-213.

112. Stone EA, Quartermain D, Lin Y, Lehmann ML. Central $\alpha 1$ adrenergic system in behavioral activity and depression. Biochem Pharmacol 2007;73:1063-1075.

113. Zhang HT, Huang Y, Mishler K, Roerig SC, O'Donnell JM. Interaction between the antidepressant-like behavioral effects of beta adrenergic agonists and the cyclic AMP PDE inhibitor rolipram in rats. Psychopharmacology (Berl) 2005;182:104-115.

114. Overstreet DH, Stemmelin J, Griebel G. Confirmation of antidepressant potential of the selective $\beta_{3}$ adrenoceptor agonist amibegron in an animal model of depression. Pharmacol Biochem Behav 2008;89:623-626.

115. Stemmelin J, Cohen C, Terranova JP, et al. Stimulation of the $\beta_{3}$-adrenoceptor as a novel treatment strategy for anxiety and depressive disorders. Neuropsychopharmacology 2008;89:574587.

116. Maurel JL, Autin JM, Funes O, Newman-Tancredi A, Colpaert F, Vacher B. High-efficacy 5- $\mathrm{HT}_{1 \mathrm{~A}}$ agonists for antidepressant treatment: a renewed opportunity. J Med Chem 2007;50:5024-5033.

117. Lucas G, Rymar VV, Du J, et al. $\operatorname{Serotonin}_{4}\left(5-\mathrm{HT}_{4}\right)$ receptor agonists are putative antidepressants with a rapid onset of action. Neuron 2007;55:712-725.

118. Svenningsson P, Tzavara ET, Qi H, et al. Biochemical and behavioral evidence for antidepressant-like effects of 5- $\mathrm{HT}_{6}$ receptor stimulation. J Neurosci 2007;27:4201-4209.

119. Wesołowska A, Nikiforuk A. The selective $5-\mathrm{HT}_{6}$ receptor antagonist SB-399885 enhances anti-immobility action of antidepressants in rats. Eur J Pharmacol 2008;582:88-93.

120. Giaroni C, Canciani L, Zanetti E, et al. Effects of chronic desipramine treatment on $\alpha 2$-adrenoceptors and $\mu$-opioid receptors in the guinea pig cortex and hippocampus. Eur J Pharmacol 2008; 579:116-125.

121. Lapiz MD, Zhao Z, Bondi CO, O’Donnell JM, Morilak DA. Blockade of autoreceptor-mediated inhibition of norepinephrine release by atipamezole is maintained after chronic reuptake inhibition. Int J Neuropsychopharmacol 2007;10:827-833.

122. Sanacora G, Berman RM, Cappiello A, et al. Addition of the $\alpha 2$-antagonist yohimbine to fluoxetine: effects on rate of antidepressant response. Neuropsychopharmacology 2004;29:11661171.
123. Gobert A, Di Cara B, Cistarelli L, Millan MJ. Piribedil enhances frontocortical and hippocampal release of acetylcholine in freely moving rats by blockade of $\alpha_{2 \mathrm{~A}}$-adrenoceptors: a dialysis comparison to talipexole and quinelorane in the absence of acetylcholinesterase inhibitors. J Pharmacol Exp Ther 2003;305: $338-346$.

124. Cordi AA, Berque-Bestel I, Persigand T, et al. Potential antidepressants display combined $\alpha_{2}$-adrenoceptor antagonist and monoamine uptake inhibitor properties. J Med Chem 2001;44: 787-805.

125. Andrés JI, Alcazar J, Alonso JM, et al. Tricyclic isoxazolines: identification of R226161 as a new antidepressant that combines potent serotonin reuptake inhibition and $\alpha 2$-adrenoceptor antagonism. Bioorg Med Chem 2007;15:3649-3660.

126. Gobert A, Cussac D, Lejeune F, et al. The novel antidepressant, S35966, is a mixed serotonin and noradrenaline reuptake inhibitor and an antagonist at $\alpha 2$-adrenoceptors. Eur Neuropsychopharmacol 2002;12 Suppl 3:S248 (abstract).

127. Pérez-García C, Morales L, Cano MV, Sancho I, Alguacil LF. Effects of histamine $\mathrm{H}_{3}$ receptor ligands in experimental models of anxiety and depression. Psychopharmacology (Berl) 1999;142: 215-220.

128. Passani MB, Lin JS, Hancock A, Crochet S, Blandina P. The histamine $\mathrm{H}_{3}$ receptor as a novel therapeutic target for cognitive and sleep disorders. Trends Pharmacol Sci 2004;25:618-625.

129. Medhurst AD, Atkins AR, Beresford IJ, et al. GSK189254, a novel $\mathrm{H}_{3}$ receptor antagonist that binds to histamine $\mathrm{H}_{3}$ receptors in Alzheimer's disease brain and improves cognitive performance in preclinical models. J Pharmacol Exp Ther 2007;321:10321045.

130. Keith JM, Gomez LA, Barbier AJ, et al. Pyrrolidino-tetrahydroisoquinolines bearing pendant heterocycles as potent dual $\mathrm{H}_{3}$ antagonist and serotonin transporter inhibitors. Bioorg Med Chem Lett 2007;17:4374-4377.

131. Barbier AJ, Aluisio L, Lord B, et al. Pharmacological characterization of JNJ-28583867, a histamine $\mathrm{H}_{3}$ receptor antagonist and serotonin reuptake inhibitor. Eur J Pharmacol 2007;576:43-54.

132. Hancock AA, Brune ME. Assessment of pharmacology and potential anti-obesity properties of $\mathrm{H}_{3}$ receptor antagonists/inverse agonists. Expert Opin Invest Drugs 2005;14:223-241.

133. Araki H, Suemaru K, Gomita Y. Neuronal nicotinic receptor and psychiatric disorders: functional and behavioral effects of nicotine. Jpn J Pharmacol 2002;88:133-138.

134. Rabenstein RL, Caldarone BJ, Picciotto MR. The nicotinic antagonist mecamylamine has antidepressant-like effects in wildtype but not $\beta_{2^{-}}$or $\alpha_{7}$-nicotinic acetylcholine receptor subunit knockout mice. Psychopharmacology (Berl) 2006;189:395-401.

135. Mineur YS, Somenzi O, Picciotto MR. Cytisine, a partial agonist of high-affinity nicotinic acetylcholine receptors, has antidepressant-like properties in male C57BL/6J mice. Neuropharmacology 2007;52:1256-1262.

136. Andreasen JT, Olsen GM, Wiborg O, Redrobe JP. Antidepressantlike effects of nicotinic acetylcholine receptor antagonists, but not agonists, in the mouse forced swim and mouse tail suspension tests. J Psychopharmacology 2008 June 26 [Epub ahead of print].

137. George TP, Sacco KA, Vessicchio JC, Weinberger AH, Shytle RD. Nicotinic antagonist augmentation of selective serotonin reuptake inhibitor-refractory major depressive disorder: a preliminary study. J Clin Psychopharmacol 2008;28:340-344.

138. Abe Y, Aoyagi A, Hara T, et al. Pharmacological characterization of RS-1259, an orally active dual inhibitor of acetylcholinesterase and serotonin transporter, in rodents: possible treatment of Alzheimer's disease. J Pharmacol Sci 2003;93:95-105.

139. Toda N, Tago K, Marumoto S, et al. A conformational restriction approach to the development of dual inhibitors of acetylcholinesterase and serotonin transporter as potential agents for Alzheimer's disease. Bioorg Med Chem 2003;11:4389-4415.

140. Decker M. Recent advances in the development of hybrid molecules/designed multiple compounds with antiamnesic properties. Mini Rev Med Chem 2007;7:221-229.

141. Froestl W, Gallagher M, Jenkins H, et al. SGS742: the first $\mathrm{GABA}_{\mathrm{B}}$ receptor antagonist in clinical trials. Biochem Pharmacol 2004;68:1479-1487. 
142. Slattery DA, Cryan JF. The role of GABA $\mathrm{B}_{\mathrm{B}}$ receptors in depression and antidepressant-related behavioural responses. Drug Dev Res 2006;67:477-494.

143. Kalueff AV, Nutt DJ. Role of GABA in anxiety and depression. Depress Anxiety 2007;24:495-517.

144. Mannoury la Cour C, Hanoun N, Melfort M, et al. $\mathrm{GABA}_{B}$ receptors in 5-HT transporter- and 5- $\mathrm{HT}_{1 \mathrm{~A}}$ knock-out mice: evidence of a transduction pathway shared with $5-\mathrm{HT}_{1 \mathrm{~A}}$ receptors. J Neurochem 2004;89:886-896.

145. Cornelisse LN, Van der Harst JE, Lodder JC, et al. Reduced $5-\mathrm{HT}_{1 \mathrm{~A}}$ and $\mathrm{GABA}_{\mathrm{B}}$ receptor function in dorsal raphe neurons upon chronic fluoxetine treatment of socially stressed rats. J Neurophysiol 2007;98:196-204.

146. Millan MJ. N-methyl-D-aspartate receptors as a target for improved antipsychotic agents: novel insights and clinical perspectives. Psychopharmacology (Berl) 2005;179:30-53.

147. Sanacora G, Rothman DL, Mason G, Krystal JH. Clinical studies implementing glutamate neurotransmission in mood disorders. Ann N Y Acad Sci 2003;1003:292-308.

148. Black MD. Therapeutic potential of positive AMPA modulators and their relationship to AMPA receptor subunits: a review of preclinical data. Psychopharmacology (Berl) 2005;179:154-163.

149. Linden AL, Schoepp DD. Metabotropic glutamate receptor targets for neuropsychiatric disorders. Drug Discov Today Ther Strateg 2006;3:507-517.

150. De Kloet ER, Joëls M, Holsboer F. Stress and the brain: from adaptation to disease. Nat Rev Neurosci 2005;6:463-475.

151. Umegaki H, Yamamoto A, Suzuki Y, Iguchi A. Stimulation of the hippocampal glutamate receptor systems induces stress-like responses. Neuro Endocrinol Lett 2006;27:339-343.

152. Ziegler DR, Cullinan WE, Herman JP. Organization and regulation of paraventricular nucleus glutamate signalling systems: $N$ methyl-D-aspartate receptors. J Comp Neurol 2005;484:43-56.

153. Rogóz Z, Skuza G, Maj J, Danysz W. Synergistic effect of uncompetitive NMDA receptor antagonists and antidepressant drugs in the forced swimming test in rats. Neuropharmacology 2002;42:1024-1030.

154. Zarate CA Jr, Singh JB, Carlson PJ, et al. A randomized trial of an $N$-methyl-D-aspartate antagonist in treatment-resistant major depression. Arch Gen Psychiatry 2006;63:856-864.

155. Maeng S, Zarate CA Jr, Du J, et al. Cellular mechanisms underlying the antidepressant effects of ketamine: role of $\alpha$-amino-3hydroxy-5-methylisoxazole-4-propionic acid receptors. Biol Psychiatry 2008;63:349-352.

156. Parsons CG, Stöffler A, Danysz W. Memantine: a NMDA receptor antagonist that improves memory by restoration of homeostasis in the glutamatergic system: too little activation is bad, too much is even worse. Neuropharmacology 2007;53:699-723.

157. Wilcock GK. Memantine for the treatment of dementia. Lancet Neurol 2003;2:503-505.

158. Karivajan H, Schneider LS. Efficacy and adverse effects of cholinesterase inhibitors and memantine in vascular dementia: a meta-analysis of randomised controlled trials. Lancet Neurol 2007;6:782-792.

159. Almeida RC, Felisbino CS, López MG, Rodrigues AL, Gabilan $\mathrm{NH}$. Evidence for the involvement of L-arginine-nitric oxidecyclic guanosine monophosphate pathway in the antidepressantlike effect of memantine in mice. Behav Brain Res 2006;168: 318-322.

160. Zarate CA Jr, Singh JB, Quiroz JA, et al. A double-blind, placebo-controlled study of memantine in depression. Am J Psychiatry 2006;163:153-155.

161. Muhonen LH, Lonnqvist J, Juva K, Alho H. Double-blind, randomized comparison of memantine and escitalopram for the treatment of major depressive disorder comorbid with alcohol dependence. J Clin Psychiatry 2008;69:392-399.

162. Bai F, Bergeron M, Nelson DL. Chronic AMPA receptor potentiator (LY451646) treatment increases cell proliferation in adult rat hippocampus. Neuropharmacology 2003;44:1013-1021.

163. Li X, Witkin JM, Need AB, Skolnick P. Enhancement of antidepressant potency by a potentiator of AMPA receptors. Cell Mol Neurobiol 2003;23:419-430.
164. Arai AC, Kessler M. Pharmacology of ampakine modulators: from AMPA receptors to synapses and behavior. Curr Drug Targets 2007;8:583-602.

165. Moriya T, Ikeda M, Teshima K, et al. Facilitation of $\alpha$-amino-3hydroxy-5-methylisoxazole-4-propionate receptor transmission in the suprachiasmatic nucleus by aniracetam enhances photic responses of the biological clock in rodents. J Neurochem 2003; 85:978-987.

166. Gould TD, O'Donnell KC, Dow ER, Du J, Chen G, Manji HK. Involvement of AMPA receptors in the antidepressant-like effects of lithium in the mouse tail suspension test and forced swim test. Neuropharmacology 2008;54:577-587.

167. Korte SM. Corticosteroids in relation to fear, anxiety and psychopathology. Neurosci Biobehav Rev 2001;25:117-142.

168. Matrisciano F, Panaccione I, Zusso M, et al. Group-II metabotropic glutamate receptor ligands as adjunctive drugs in the treatment of depression: a new strategy to shorten the latency of antidepressant medication? Mol Psychiatry 2007;12:704-706.

169. Brocco M, Dekeyne A, Mannoury la Cour C, et al. Cellular and behavioural profile of the novel, selective neurokinin receptor antagonist, vestipitant: a comparison to other agents. Eur Neuropsychopharmacol 2008;18:729-750.

170. Czéh B, Fuchs E, Simon M. NK N $_{1}$ receptor antagonists under investigation for the treatment of affective disorders. Expert Opin Investig Drugs 2006;15,479-486.

171. Kramer MS, Winokur A, Kelsey J, et al. Demonstration of the efficacy and safety of a novel substance $\mathrm{P}\left(\mathrm{NK}_{1}\right)$ receptor antagonist in major depression. Neuropsychopharmacology 2004;29: 385-392.

172. Keller M, Montgomery S, Ball W, et al. Lack of efficacy of the substance $\mathrm{P}$ (neurokinin ${ }_{1}$ receptor) antagonist aprepitant in the treatment of major depressive disorder. Biol Psychiatry 2006;59: 216-223.

173. Millan MJ, Lejeune F, De Nanteuil G, Gobert A. Selective blockade of $\mathrm{NK}_{1}$ receptors facilitates the activity of adrenergic pathways projecting to frontal cortex and dorsal hippocampus in rats. J Neurochem 2001;76:1949-1954.

174. Lejeune F, Gobert A, Millan MJ. The selective $\mathrm{NK}_{1}$ antagonist, GR205,171, stereospecifically enhances mesocortical dopaminergic transmission in the rat: a combined dialysis and electrophysiological study. Brain Res 2002;935:134-139.

175. Gobbi G, Cassano T, Radja F, et al. Neurokinin 1 receptor antagonism requires norepinephrine to increase serotonin function. Eur Neuropsychopharmacol 2007;17:328-338.

176. Guiard BP, Guilloux JP, Reperant C, Hunt SP, Toth M, Gardier AM. Substance $\mathrm{P}$ neurokinin 1 receptor activation within the dorsal raphe nucleus controls serotonin release in the mouse frontal cortex. Mol Pharmacol 2007;72:1411-1418.

177. Gobert A, Brocco M, Dekeyne A, et al. Neurokinin ${ }_{1}$ antagonists potentiate antidepressant properties of serotonin reuptake inhibitors, yet blunt their anxiogenic actions: a neurochemical, electrophysiological, and behavioral characterization. Neuropsychopharmacology 2008 Oct. 1 [Epub ahead of print].

178. Chenu F, Guiard BP, Bourin M, Gardier AM. Antidepressant-like activity of selective serotonin reuptake inhibitors combined with a $\mathrm{NK}_{1}$ receptor antagonist in the mouse forced swimming test. Behav Brain Res 2006;172:256-263.

179. Millan MJ, Girardon S, Mullot J, Brocco M, Dekeyne A. Stereospecific blockade of marble-burying behaviour in mice by selective, non-peptidergic neurokinin ${ }_{1}\left(\mathrm{NK}_{1}\right)$ receptor antagonists. Neuropharmacology 2002;42:677-684.

180. Gannon RL, Millan MJ. The selective tachykinin neurokinin 1 $\left(\mathrm{NK}_{1}\right)$ receptor antagonist, GR205,171, stereospecifically inhibits light-induced phase advances of hamster circadian activity rhythms. Eur J Pharmacol 2005;527:86-93.

181. Gannon RL, Millan MJ. Evaluation of serotonin, noradrenaline and dopamine reuptake inhibitors on light-induced phase advances in hamster circadian activity rhythms. Psychopharmacology (Berl) 2007;195:325-332.

182. Patel L, Lindley C. Aprepitant: a novel NK1-receptor antagonist. Expert Opin Pharmacother 2003;4:2279-2296.

183. Ryckmans T, Balançon L, Berton O, et al. First dual $\mathrm{NK}_{1}$ antagonists-serotonin reuptake inhibitors: synthesis and SAR of a 
new class of potential antidepressants. Bioorg Med Chem Lett 2002;12:261-264.

184. Louis C, Stemmelin J, Boulay D, Bergis O, Cohen C, Griebel G. Additional evidence for anxiolytic- and antidepressant-like activities of saredutant (SR48968), an antagonist at the neurokinin-2 receptor in various rodent models. Pharmacol Biochem Behav 2008;89:36-45.

185. Micale V, Tamburella A, Leggio GM, Mazzola C, Li VV, Drago F. Behavioral effects of saredutant, a tachykinin NK2 receptor antagonist, in experimental models of mood disorders under basal and stress-related conditions. Pharmacol Biochem Behav 2008; 90:463-469.

186. Serradeil-Le Gal C, Wagnon J 3rd, Tonnerre B, et al. An overview of SSR149415, a selective nonpeptide vasopressin V1b receptor antagonist for the treatment of stress related disorders. CNS Drug Rev 2005;11:53-68.

187. Landgraf R. The involvement of the vasopressin system in stressrelated disorders. CNS Neurol Disord Drug Targets 2006;5:167179 .

188. Hodgson RA, Higgins GA, Guthrie DH, et al. Comparison of the V1b antagonist, SSR149415, and the CRF1 antagonist, CP154,526, in rodent models of anxiety and depression. Pharmacol Biochem Behav 2007;86:431-440.

189. Ogren SO, Kuteeva E, Hokfelt T, Kehr J. Galanin receptor antagonists: a potential novel pharmacological treatment for mood disorders. CNS Drugs 2006;20:633-654.

190. Millan MJ, Gobert A, Panayi F, et al. The melanin-concentrating hormone $_{1}$ receptor antagonists, SNAP-7941 and GW3430, enhance social recognition and dialysate levels of acetylcholine in the frontal cortex of rats. Int J Neuropsychopharmacol 2008;11: $1105-1122$.

191. Kehne JH. The CRF1 receptor, a novel target for the treatment of depression, anxiety, and stress-related disorders. CNS Neurol Disord Drug Targets 2007;6:163-182.

192. Binneman B, Feltner D, Kolluri S, Shi Y, Qiu R, Stiger T. A 6-week randomized, placebo-controlled trial of CP-316,311 (a selective $\mathrm{CRH}_{1}$ antagonist) in the treatment of major depression. Am J Psychiatry 2008;165:617-620.

193. Xi N. The MC4 receptor as a drug discovery target. Drugs Fut 2006;31:163-173.

194. Chaki S, Oshida Y, Ogawa S, et al. MCL0042: a nonpeptidic MC4 receptor antagonist and serotonin reuptake inhibitor with anxiolytic- and antidepressant-like activity. Pharmacol Biochem Behav 2005;82:621-626.

195. Della Zuana O, Sadlo M, Germain M, Félétou M, Chamorro S, Tisserand F. Reduced food intake in response to CGP 71683A may be due to mechanisms other than NPY Y5 receptor blockade. Int J Obes Relat Metab Disord 2001;25:84-94.

196. Gold PW, Chrousos GP. Organization of the stress system and its dysregulation in melancholic and atypical depression: high vs low CRH/NE states. Mol Psychiatry 2002;7:254-275.

197. DeBattista C, Belanoff J. The use of mifepristone in the treatment of neuropsychiatric disorders. Trends Endocrinol Metab 2006;17: 117-121.

198. Schick M, Kiefer F, Kämpf P, Arlt J, Wiedemann K, Jahn H. Cell-turnover in the gyrus dentatus in mice is enhanced by metyrapone treatment. Pharmacopsychiatry 2001;34:198.

199. Rogóz Z, Skuza G, Wójcikowski J, Daniel WA. Effects of combined treatment with imipramine and metyrapone in the forced swimming test in rats. Behavioral and pharmacokinetic studies. Pol J Pharmacol 2003;55:993-999.

200. Rogóz Z, Skuza G, Wójcikowski J, et al. Effect of metyrapone supplementation on imipramine therapy in patients with treatment-resistant unipolar depression. Pol J Pharmacol 2004;56: $849-855$

201. Jahn H, Schick M, Kiefer F, Kellner M, Yassouridis A, Wiedermann K. Metyrapone as additive treatment in major depression. Arch Gen Psychiatry 2004;61:1235-1244.

202. Gallagher P, Malik N, Newham J, Young AH, Ferrier IN, Mackin P. Antiglucocorticoid treatments for mood disorders. Cochrane Database Syst Rev 2008;(1):CD005168.

203. Oomen CA, Mayer JL, de Kloet ER, Joëls M, Lucassen PJ. Brief treatment with the glucocorticoid receptor antagonist mifepris- tone normalizes the reduction in neurogenesis after chronic stress. Eur J Neurosci 2007;26:3395-3401.

204. Wu LM, Han H, Wang QN, et al. Mifepristone repairs regiondependent alteration of synapsin I in hippocampus in rat model of depression. Neuropsychopharmacology 2007;32:2500-2510.

205. Ago Y, Arikawa S, Yata M, et al. Antidepressant-like effects of the glucocorticoid receptor antagonist RU-43044 are associated with changes in prefrontal dopamine in mouse models of depression. Neuropharmacology 2008 Aug. 30 [Epub ahead of print].

206. Schatzberg AF, Lindley S. Glucocorticoid antagonists in neuropsychiatric disorders. Eur J Pharmacol 2008;583:358-364.

207. Clark JA, Pai LY, Flick RB, Rohrer SP. Differential hormonal regulation of tryptophan hydroxylase-2 mRNA in the murine dorsal raphe nucleus. Biol Psychiatry 2005;57:943-946.

208. Johnson DA, Grant EJ, Ingram CD, Gartside SE. Glucocorticoid receptor antagonists hasten and augment neurochemical responses to a selective serotonin reuptake inhibitor antidepressant. Biol Psychiatry 2007;62:1228-1235.

209. Zupancic M, Guilleminault C. Agomelatine. CNS Drugs 2006; 20:981-992.

210. Ghosh A, Hellewell JSE. A review of the efficacy and tolerability of agomelatine in the treatment of major depression. Expert Opin Investig Drugs 2007;16:1999-2004.

211. Lam RW. Addressing circadian rhythm disturbances in depressed patients. J Psychopharmacology 2008;22:13-18.

212. Srinivasan V, Smits M, Spence W, et al. Melatonin in mood disorders. World J Biol Psychiatry 2006;7:138-151.

213. Lemoine P, Nir T, Laudon M, Zisapel N. Prolonged-release melatonin improves sleep quality and morning alertness in insomnia patients aged 55 years and older and has no withdrawal effects. J Sleep Res 2007;16:372-380.

214. Weil ZM, Hotchkiss AK, Gatien ML, Pieke-Dahl S, Nelson RJ. Melatonin receptor (MT1) knockout mice display depression-like behaviors and deficits in sensorimotor gating. Brain Res Bull 2006;68:425-429.

215. Millan MJ, Brocco, Gobert A, Dekeyne A. Anxiolytic properties of agomelatine, an antidepressant with melatoninergic and serotonergic properties: role or 5- $\mathrm{HT}_{2 \mathrm{C}}$ receptor blockade. Psychopharmacology (Berl) 2005;177:448-458

216. Millan MJ, Gobert A, Lejeune F, et al. The novel melatonin agonist agomelatine (S20098) is an antagonist at $5-\mathrm{HT}_{2 \mathrm{C}}$ receptors, blockade of which enhances the activity of frontocortical dopaminergic and adrenergic pathways. J Pharmacol Exp Ther 2003;306:954-964.

217. Banasr M, Soumier A, Hery M, Mocaër E, Daszuta A. Agomelatine, a new antidepressant, induces regional changes in hippocampal neurogenesis. Biol Psychiatry 2006;59:1087-1096.

218. Kennedy SH, Emsley R. Placebo-controlled trial of agomelatine in the treatment of major depressive disorder. Eur Neuropsychopharmacol 2006;16:93-100.

219. Kennedy SH, Rizvi S, Fulton K, Rasmussen J. A double-blind comparison of sexual functioning, antidepressant efficacy, and tolerability between agomelatine and venlafaxine XR. J Clin Psychopharmacol 2008;28:329-333.

220. Chenu F, Bourin M. Potentiation of antidepressant-like activity with lithium: mechanism involved. Curr Drug Targets 2006;7: 159-163.

221. Crossley NA, Bauer M. Acceleration and augmentation of antidepressants with lithium for depressive disorders: two meta-analyses of randomized, placebo-controlled trials. J Clin Psychiatry 2007;68:935-940.

222. Carbonell L, Cuffi ML, Forn J. Effect of chronic lithium treatment on the turnover of $\alpha 2$-adrenoceptors after chemical inactivation in rats. Eur Neuropsychopharmacol 2004;14:497-502.

223. Gould TD, Manji HK. Glycogen synthase kinase-3: a putative molecular target for lithium mimetic drugs. Neuropsychopharmacology 2005;30:1223-1237.

224. Jope RS, Roh MS. Glycogen synthase kinase-3 (GSK-3) in psychiatric diseases and therapeutic interventions. Curr Drug Targets 2006;7:1421-1434.

225. Rowe MK, Wiest C, Chuang DM GSK-3 is a viable potential target for therapeutic intervention in bipolar disorder. Neurosci Biobehav Rev 2007;31:920-931. 
226. Li X, Zhu W, Roh MS, Friedman AB, Rosborough K, Jope RS In vivo regulation of glycogen synthase kinase- $3 \beta$ (GSK-3 $\beta$ ) by serotonergic activity in mouse brain. Neuropsychopharmacology 2004;29:1426-1431.

227. Nowak G, Siwek M, Dudek D, Zieba A, Pilc A. Effect of zinc supplementation on antidepressant therapy in unipolar depression: a preliminary placebo-controlled study. Pol J Pharmacol 2003;55:1143-1147.

228. Kaidanovich-Beilin O, Milman A, Weizman A, Pick CG, EldarFinkelman H. Rapid antidepressive-like activity of specific glycogen synthase kinase- 3 inhibitor and its effect on $\beta$-catenin in mouse hippocampus. Biol Psychiatry 2004;55:781-784.

229. Rosa AO, Kaster MP, Binfaré RW, et al. Antidepressant-like effect of the novel thiadiazolidinone NP031115 in mice. Prog Neuropsychopharmacol Biol Psychiatry 2008;32:1549-1556.

230. Ghavami A, Hirst WD, Novak TJ. Selective phosphodiesterase (PDE)-4 inhibitors: a novel approach to treating memory deficit? Drugs R D 2006;7:63-71.

231. Zhang HT, Huang Y, Masood A, et al. Anxiogenic-like behavioral phenotype of mice deficient in phosphodiesterase 4B (PDE4B). Neuropsychopharmacology 2008;33:1611-1623.

232. Zhang HT, Zhao Y, Huang Y, Dorairaj NR, Chandler LJ, O'Donnell JM. Inhibition of PDE-4 reverses memory deficits produced by infusion of the MEK inhibitor U0126 into the CAI subregion of the rat hippocampus. Neuropsychopharmacology 2004;29:1432-1439.

233. Millan MJ. The role of monoamines in the actions of established and "novel" antidepressant agents: a critical review. Eur J Pharmacol 2004;500:371-384.

234. Chanrion B, Mannoury la Cour C, Bertaso F, et al. Physical interaction between serotonin transporter and neuronal nitric oxide synthase underlies reciprocal modulation of activity. Proc Natl Acad Sci U S A 2007;104:8119-8124.

235. Hayashi T, Su TP. Sigma-1 receptor chaperones at the ERmitochondrion interface regulate $\mathrm{Ca}^{2+}$ signaling and cell survival. Cell 2007;131:596-610.

236. Martina M, Turcotte MEB, Halman S, Bergeron R. The sigma-1 receptor modulates NMDA receptor synaptic transmission and plasticity via SK channels in rat hippocampus. J Physiol 2007; 578.1;143-157.

237. Wang J, Mack AL, Coop A, Matsumoto RR. Novel sigma $(\sigma)$ receptor agonists produce antidepressant-like effects in mice. Eur Neuropsychopharmacol 2007;17:708-716.

238. Paolini GV, Shapland RHB, van Hoorn WP, Mason JS, Hopkins AL. Global mapping of pharmacological space. Nat Biotechnol 2006;24:805-815.

239. Campillos M, Kuhn M, Gavin AC, Jensen LJ, Bork P. Drug target identification using side-effect similarity. Science 2008;321:263266.

240. Hellerstein MK. Exploiting complexity and the robustness of network architecture for drug discovery. J Pharmacol Exp Ther 2008;325:1-9.

241. Evrard DA. Recent strategies for the development of new antidepressant drugs. Annu Rep Med Chem 2006;41:24-37.

242. Hopkins AL, Mason JS, Overington JP. Can we rationally design promiscuous drugs? Curr Opin Structural Biol 2006;16:127-136.

243. Yeh P, Tschumi AI, Kishony R. Functional classification of drugs by properties of their pairwise interactions. Nat Genet 2006;38: 489-494.

244. Yildirim MA, Goh KI, Cusick ME, Barabási AL, Vidal M. Drugtarget network. Nat Biotechnol 2007;25:1119-1126.

245. Keiser MJ, Roth BL, Armbruster BN, Ernsberger P, Irwin JJ, Shoichet BK. Relating protein pharmacology by ligand chemistry. Nat Biotechnol 2007;25:197-206.

246. Jenwitheesuk E, Horst JA, Rivas KL, Van Voorhis WC, Samudrala R. Novel paradigms for drug discovery: computational multi-target screening. Trends Pharmacol Sci 2008;29:62-71.

247. Kwak EL, Clark JW, Chabner B. Targeted agents: the rules of combination. Clin Cancer Res 2007;13:5232-5237.

248. Zimmermann GR, Lehar J, Keith CT. Multi-target therapeutics: when the whole is greater than the sum of the parts. Drug Discov Today 2007;12:34-42.
249. Newman MEJ. The structure and function of complex networks. SIAM Rev 2003;45:167-256.

250. Sporns O. Network analysis, complexity, and brain function. Complexity 2003;8:56-60.

251. Csete M, Doyle J. Bow ties, metabolism and disease. Trends Biotechnol 2004;22:446-450.

252. Achard S, Salvador R, Whitcher B, Suckling J, Bullmore E. A resilient, low-frequency, small-world human brain functional network with highly connected association cortical hubs. J Neurosci 2006;26:63-72.

253. Micheloyannis S, Pachou E, Stam CJ, Breakspear M, Bitsios P, Vourkas M. Small-world networks and disturbed functional connectivity in schizophrenia. Schizophr Res 2006;87:60-66.

254. Araujo RP, Liotta LA, Petricoin EF. Proteins, drug targets and the mechanisms they control: the simple truth about complex networks. Nat Rev Drug Discov 2007;6:871-880.

255. He Y, Chen ZJ, Evans AC. Small-world anatomical networks in the human brain revealed by cortical thickness from MRI. Cereb Cortex 2007;17:2407-2419.

256. Ideker T, Sharan R. Protein networks in disease. Genome Res 2008;18:644-652.

257. May RM. Network structure and biology of populations. Trends Ecol Evol 2006;21:394-399.

258. Proulx SR, Promislow DEL, Phillips PC. Network thinking in ecology and evolution. Trends Ecol Evol 2005;20:345-353.

259. Schrattenholz A, Soskic V. What does systems biology mean for drug development? Curr Med Chem 2008;15:1520-1528.

260. Fujisawa S, Matsuki N, Ikegaya Y. Single neurons can induce phase transitions of cortical recurrent networks with multiple internal states. Cereb Cortex 2006;16:639-654.

261. Kaiser M, Martin R, Andras P, Young MP. Simulation of robustness against lesions of cortical networks. Eur J Neurosci 2007; 25:3185-3192.

262. Stam CJ, Jones BF, Nolte G, Breakspear M, Scheltens P. Smallworld networks and functional connectivity in Alzheimer's disease. Cereb Cortex 2007;17:92-99.

263. Szalay MS, Kovacs IA, Korcsmáros T, Böde C, Csermely P. Stress-induced rearrangements of cellular networks: consequences for protection and drug design. FEBS Lett 2007;581: $3675-3680$.

264. Lawson K. Pharmacological treatments of fibromyalgia: do complex conditions need complex therapies? Drug Discov Today 2008:13:333-340.

265. Lin D, Mok H, Yatham LN. Polytherapy in bipolar disorder. CNS Drugs 2006;20:29-42.

266. Van der Schyf CJ, Geldenhuys WJ, Youdim MBH. Multifunctional neuroprotective-neurorescue drugs for Parkinson's disease. Future Neurol 2007;2:411-423.

267. Pinnen F, Cacciatore I, Cornacchia C, et al. Synthesis and study of L-dopa-glutathione codrugs as new anti-Parkinson agents with free radical scavenging properties. J Med Chem 2007;50:25062515.

268. Bolognesi ML, Cavalli A, Valgimigli L, et al. Multi-target-directed drug design strategy: from a dual binding site acetylcholinesterase inhibitor to a trifunctional compound against Alzheimer's disease. J Med Chem 2007;50:6446-6449.

269. Mandel S, Amit T, Bar-Am O, Youdim MBH. Iron dysregulation in Alzheimer's disease: multimodal brain permeable iron chelating drugs, possessing neuroprotective-neurorescue and amyloid processing regulatory activities as therapeutic agents. Prog Neurobiol 2007;82:348-360.

270. Doody RS, Gavrilova SI, Sano M, et al. Effect of dimebon on cognition, activities of daily living, behaviour, and global function in patients with Alzheimer's disease: a randomised, doubleblind, placebo-controlled study. Lancet 2008;372:207-215.

271. Piazzi L, Cavalli A, Colizzi F, et al. Multi-target-directed coumarin derivatives: $\mathrm{hAChE}$ and BACE1 inhibitors as potential anti-Alzheimer compounds. Bioorg Med Chem Lett 2008;18: 423-426.

272. Araujo RP, Doran C, Liotta LA, Petricoin EF. Network-targeted combination therapy: a new concept in cancer treatment. Drug Discov Today Ther Strateg 2004;1:425-433. 
273. Schenone S, Manetti F, Botta M. Last findings on dual inhibitors of Abl and Src tyrosine-kinases. Mini Rev Med Chem 2007;7: 191-201.

274. Petrelli A, Giordano S. From single- to multi-target drugs in cancer therapy: when aspecificity becomes an advantage. Curr Med Chem 2008;15:422-432.

275. López-Muñoz F, Alamo C, Rubio G, García-García P, Pardo A. Reboxetine combination in treatment-resistant depression to se- lective serotonin reuptake inhibitors. Pharmacopsychiatry 2007;40:14-19.

276. Plenge P, Gether U, Rasmussen SG. Allosteric effects of $R$ - and $S$-citalopram on human 5-HT transporter: evidence for distinct highand low-affinity binding sites. Eur J Pharmacol 2007;567:1-9.

277. Höschl C, Svestka J. Escitalopram for the treatment of major depression and anxiety disorders. Expert Rev Neurother 2008;8: 537-552. 